\title{
Breakdown in Peripheral Tolerance in Type 1 Diabetes in Mice and Humans
}

\author{
Lukas T. Jeker, Hélène Bour-Jordan, and Jeffrey A. Bluestone \\ UCSF Diabetes Center, University of California at San Francisco, San Francisco, California 94143 \\ Correspondence: Jeff.Bluestone@ucsf.edu
}

Type 1 Diabetes (T1D), also called juvenile diabetes because of its classically early onset, is considered an autoimmune disease targeting the insulin-producing $\beta$ cells in the pancreatic islets of Langerhans. T1D reflects a loss of tolerance to tissue self-antigens caused by defects in both central tolerance, which aims at eliminating potentially autoreactive lymphocytes developing in the thymus, and peripheral tolerance, which normally controls autoreactive T cells that escaped the thymus. Like in other autoimmune diseases, the mechanisms leading to T1D are multifactorial and depend on a complex combination of genetic, epigenetic, molecular, and cellular elements that result in the breakdown of peripheral tolerance. In this article, we discuss the contribution of these factors in the development of the autoimmune response targeting pancreatic islets in T1D and the therapeutic strategies currently being explored to correct these defects.

$T^{\mathrm{h}}$ he immune system is a finely tuned network of intertwined pathways that work to recognize, respond to, and eliminate infectious agents while refraining from self-inflicted tissue destruction. The fundamental self versus nonself discrimination starts in the earliest days of development when the white blood T-cell system first forms in the thymus. T-cell development is based on an inherent selection system wherein maturing thymocytes encounter small self peptides bound to cell surface molecules, termed major histocompatibility complex (MHC) proteins, that simultaneously skew the repertoire toward self-recognition whereas eliminating mature $\mathrm{T}$ cells expressing a $\mathrm{T}$-cell receptor (TCR) with too high an affinity for self-peptides bound to the MHC selecting molecules. However, this process of negative selection, termed central tolerance, is not complete as some autoreactive $\mathrm{T}$ cells escape selection, either because of the absence of certain peptide-MHC complexes in the thymus, or genetic defects or variants that compromise the thymic selection process. Fortunately, in most individuals, back-up processes control potentially autoreactive $\mathrm{T}$ cells in the periphery. These processes include the active elimination of self-reactive $\mathrm{T}$ cells through inappropriate peptide-MHC recognition leading to cell death or inactivation as well as dominant regulatory processes that shut down the potentially autoreactive T cells. Unfortunately, in some individuals, genetic predisposition, combined with environmental stresses can lead to a breakdown in peripheral tolerance leading to autoimmunity. Type 1 Diabetes (T1D) is an example of one such autoimmune

Editors: Jeffrey A. Bluestone, Mark A. Atkinson, and Peter R. Arvan

Additional Perspectives on Type I Diabetes available at www.perspectivesinmedicine.org

Copyright (C) 2012 Cold Spring Harbor Laboratory Press; all rights reserved; doi: 10.1101/cshperspect.a007807

Cite this article as Cold Spring Harb Perspect Med 2012;2:a007807 


\section{L.T. Jeker et al}

disease wherein the breakdown in tolerance leads to the initiation and progressive destruction of the insulin-producing $\beta$ cells. In this article, we describe the key players in this saga. We highlight the multifactorial events that lead to the breakdown of peripheral tolerance and development of the disease. Finally, we discuss ongoing clinical efforts to develop therapeutic approaches to repair and reinstate immune homeostasis to treat and prevent this devastating disease.

\section{ACTIVATION AND FUNCTION OF PATHOGENIC T-CELL POPULATIONS}

The pathogenesis of $\mathrm{T} 1 \mathrm{D}$ remains unclear, but clues to its origins and etiology can be gathered from studies of both nonobese diabetic (NOD) mice and humans (Fig. 1). For instance, it is widely believed that pathogenic autoreactive T cells, which infiltrate (so-called "insulitis") and destroy the pancreatic islets, mediate T1D. Both $\mathrm{CD}^{+}$and $\mathrm{CD} 8^{+} \mathrm{T}$ cells can transfer disease in the NOD mouse model of T1D (Anderson and Bluestone 2005). Additionally, T cells specific for islet self-antigens, including insulin, glutamic acid decarboxylase 65 (GAD65), insulinoma-associated protein 2 (IA2), zinc transporter 8 (ZnT8), and islet-specific glucose-6phosphatase catalytic subunit-related protein (IGRP), have been found in the islets and peripheral blood of NOD mice and T1D patients, respectively (Lieberman and DiLorenzo 2003). Autoantibodies targeting some of these islet antigens are used as diagnostic and prognostic tools in the clinic. However, these autoantibodies are not believed to be directly pathogenic and the important role of $\mathrm{B}$ cells in diabetes is instead related to their efficient presentation of self-antigens to autoreactive $\mathrm{T}$ cells (Wong et al. 2004; Bour-Jordan et al. 2007). The activation of autoreactive T cells in NOD mice is initiated by dendritic cells (DCs) presenting islet self-antigens in the draining pancreatic lymph nodes (LN) following a wave of $\beta$-cell death of unexplained etiology early in life (Turley et al. 2003). Further immune-mediated tissue damage results in additional shedding of islet antigens and epitope spreading in the autoreactive
T-cell response, leading to infiltration of the tissue by a diverse population of autoreactive $\mathrm{T}$ cells that nevertheless are predominantly tissue-specific rather than recruited by bystander mechanisms (Lennon et al. 2009). Thus, after an unknown initial hit, priming of autoreactive $\mathrm{T}$ cells in the pancreatic LN represents the first step toward autoimmune diabetes.

For autoreactive $\mathrm{CD}^{+} \mathrm{T}$ cells, tolerance is achieved by immunological ignorance if the level of self-antigen presentation in the draining LN (dLN) is low, and by anergy or death, which is mediated by Bim, the proapoptotic protein when expressed at high levels. The ability to break tolerance depends both on the avidity of TCR-self-antigen interactions and the status of DCs presenting self-antigens in the pancreatic LN (Dissanayake et al. 2011). Indeed, the phenotypic and functional status of DCs and the DC subset involved in presentation are critical to determine whether DCs will promote tolerance or present antigen in an immunogenic manner. Additionally, the avidity of interactions between autoreactive TCR and their cognate antigen presented by DCs must reach a certain threshold to trigger the activation of autoreactive $\mathrm{CD}^{+} \mathrm{T}$ cells in pancreatic LN and their pathogenic potential in the tissue (Gronski et al. 2004). In this regard, it has been shown that progression from insulitis to diabetes was driven by "avidity maturation" of islet-specific CD ${ }^{+}$T cells (Amrani et al. 2000). Additionally, among many known inhibitory molecules, CTLA-4 and Cbl-b are important to prevent T1D as they can increase the threshold for TCR signaling and represent crucial cell-intrinsic brakes for the activation of autoreactive T cells in pancreatic LN (Ausubel et al. 2002; Walker et al. 2002; Eggena et al. 2004; Gronski et al. 2004; Hoyne et al. 2011). Of note, the influence of negative regulators of TCR signaling on tolerance can be complex and is not necessarily limited to the periphery. For example, polymorphisms in the T1D susceptibility gene PTPN22 encoding the lymphoid protein tyrosine phosphatase (LYP), which negatively regulates TCR signaling, have been characterized as gain-of-function mutations that result in lower T-cell activation and IL-2 production (Vang et al. 2005). This, in turn, may lead to 

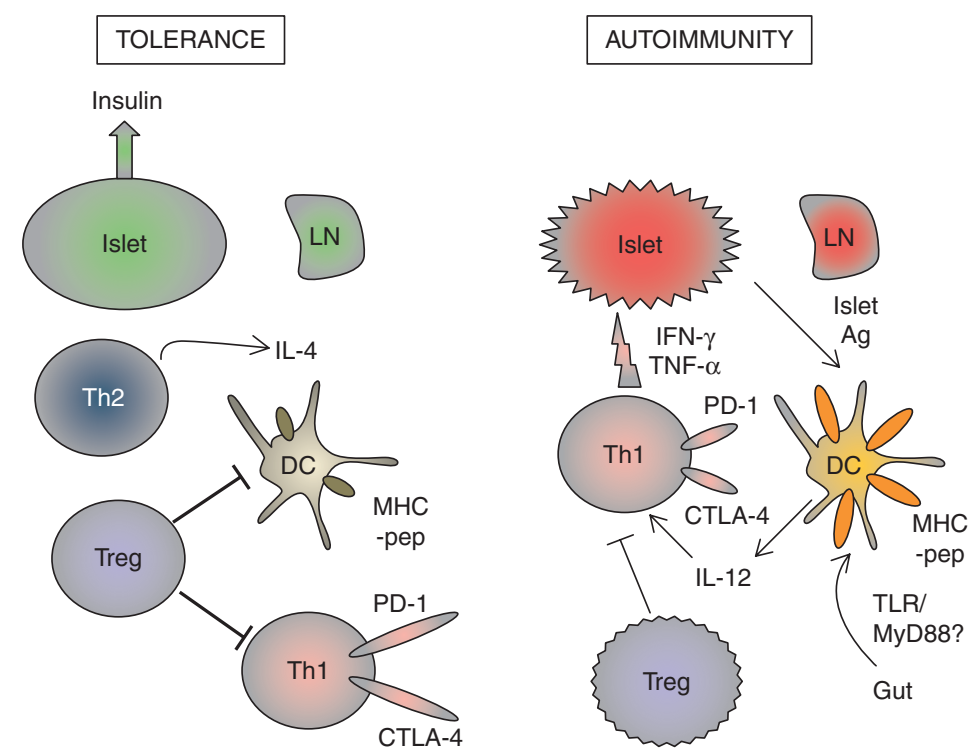

Figure 1. Cellular and molecular components of tolerance versus autoimmunity. This figure schematically describes the major cell subsets involved in tolerogenic versus autoimmune conditions in the pancreatic LN and islets (see text for details). In tolerance (left panel), DCs express low amounts of self-antigen-MHC complexes and do not efficiently stimulate autoreactive T cells (designated as $\mathrm{CD} 4{ }^{+}$Th1 for simplification but could also be autoreactive $\mathrm{CD}^{+} \mathrm{T}$ cells); Tregs efficiently suppress Teff; effector responses are skewed toward the protective Th2 subset; and intrinsic inhibitory molecules such as CTLA-4 and PD-1 control Teff in the LN and tissue. In autoimmunity (right panel), DCs are functionally mature with high levels of self-antigen-MHC complexes, costimulatory molecules (not shown) and proinflammatory cytokines such as IL-12; DC function is initiated and/or amplified by the release of self-antigens following tissue damage and potentially the influence of the gut; Teff escape Treg-mediated immunoregulation because of both defective numbers, survival and/or function of Tregs and resistance of Teff to suppression; effector responses are predominated by proinflammatory Th1 cells; Teff are not efficiently controlled by immunoregulatory molecules such as CTLA- 4 and PD- 1 . The autoimmune process ultimately results in destruction of pancreatic islets and deficient insulin production.

both thymic selection of autoreactive cells caused by defects in TCR signal strength and negative selection, and suboptimal IL-2 production by effector $\mathrm{T}$ cells in the islets that could locally compromise immunoregulation by Tregs, as discussed later in this article.

Importantly, it is becoming clear that recognition of self-antigen on antigen-presenting cells (APCs) other than tolerogenic DCs may play a role in the maintenance of peripheral tolerance. Stromal cells have been recently shown to present tissue-specific antigens (TSAs) in LNs, through mechanisms involving the transcription factors Autoimmune Regulator (Aire) or Deformed Epidermal Autoregulatory Factor 1 (Deaf1) (Lee et al. 2007; Gardner et al. 2009). Presentation of islet antigens by stromal cells in pancreatic LN may participate in tolerizing autoreactive $\mathrm{T}$ cells by inducing their deletion and may thus be involved in preventing diabetes in mice and humans (Lee et al. 2007; Gardner et al. 2008; Yip et al. 2009). In this regard, mutations in genes coding for Aire and PTPN22 have been associated with T1D (Bottini et al. 2004, 2006). Additionally, polymorphisms in the promoter region of the insulin gene contribute to disease susceptibility (Pugliese et al. 1997), possibly by affecting the ability of Aire to mediate thymic epithelial expression of insulin as a self-antigen during negative selection. Taken together, these findings reflect the qualitative as well as quantitative role of the presentation of islet antigens and the level of TCR signaling in the thymus and the periphery in the 
maintenance of peripheral tolerance (see Fig. 1 in Gardner et al. 2009).

Finally, the subset of T cells activated by selfantigens and, in particular, their cytokine production may be important for the outcome of the immune response. There has long been a general consensus that proinflammatory Th1 cells (producing IFN- $\gamma$ ) tend to be pathogenic whereas Th2 cells (producing IL-4) can protect from diabetes in the NOD mouse. The diabetogenic role of Th1 cells was suggested by numerous studies, including prevention of diabetes by anti-IFN- $\gamma$ monoclonal antibodies (mAbs) in NOD mice, abrogation of disease in IFN- $\gamma$ deficient mice in the RIP-LCMV TCR-transgenic (TCR-Tg) model of diabetes, and protection from diabetes in NOD mice deficient for the Th1 lineage-specific transcription factor T-bet (Debray-Sachs et al. 1991; von Herrath and Oldstone 1997; Esensten et al. 2009). The protective role of IL-4 in autoimmune diabetes has been suggested by a converging array of evidence including decreased diabetes incidence in NOD mice treated with exogenous IL-4 (Rapoport et al. 1993) or expressing IL-4 in pancreatic islets (Mueller et al. 1996), decreased diabetes after injection of islet-specific $\mathrm{T}$ cells expressing high levels of IL-4 (Tian et al. 1996; Ploix et al. 1998), the association of tolerogenic therapies or regulatory cell types such as NKT cells with IL-4 production (Elias et al. 1997; Hammond et al. 1998) and the inverse correlation of disease severity with IL-4 (Lenschow et al. 1996; Fox and Danska 1997). However, the incidence of diabetes was not dramatically affected in NOD mice genetically deficient for IFN- $\gamma$ (Hultgren et al. 1996; Serreze et al. 2001) or for IL-4 (Wang et al. 1998), suggesting that deficiency in either cytokine alone was not sufficient to modify disease progression. Rather, the pathogenic versus tolerogenic role of IFN- $\gamma$ versus IL-4 likely reflects a more complex pattern of cell populations and cellular interactions involved in promoting autoimmunity or favoring tolerance. Furthermore, this paradigm has to be reexamined in view of the recent realization that there is a certain degree of plasticity in T-cell subsets (Zhou et al. 2009a; O'Shea and Paul 2010), which implies that the contribution and stability of a given cell subset during the autoimmune response may vary depending on epigenetic factors and the immunological environment. In this regard, it was recently shown that proinflammatory Th17 cells, which have been implicated in many autoimmune diseases (Korn et al. 2009), only induce diabetes after conversion into IFN- $\gamma$-producing Th1-like cells (Bending et al. 2009; Martin-Orozco et al. 2009).

\section{INTRINSIC CONTROL OF PATHOGENIC T CELLS}

Successful activation of T cells to promote autoimmunity, including T1D, requires two signals, the TCR signal 1 and costimulatory signal 2 . This concept has become a paradigm for understanding the positive activation events needed to initiate immunity. However, over the last 15 years, it has become increasingly apparent that there are negative regulatory receptors that control immunity. The cell surface receptor/ligand pairs are quintessential for maintaining homeostasis by tempering normal immunity and shutting down unwanted immune responses. Two of the best-characterized negative regulators are, Cytotoxic T-lymphocyte antigen-4 (CTLA-4) and Programmed death-1 (PD-1) (Bour-Jordan and Bluestone 2009). These molecules are related members of the CD28 family but are selectively expressed on activated $\mathrm{T}$ cells and when engaged shut down immune activation to promote T-cell homeostasis and peripheral tolerance. CTLA- 4 and PD-1 are both important to maintain peripheral tolerance and control autoimmune diabetes in the NOD strain. Although NOD mice deficient for CTLA-4 die at 3-4 weeks of age of a massive lymphoproliferative disease (LPD), as in other genetic backgrounds, CTLA-4KO islet-antigen specific BDC2.5 TCR-Tg mice develop autoimmune diabetes with higher incidence and earlier onset compared with CTLA-4 sufficient animals (Luhder et al. 2000). Conversely, triggering of CTLA-4 signaling by a single-chain membranebound anti-CTLA-4 Ab transgene (scoCTLA- 4 $\mathrm{Tg}$ ) expressed on B cells altered the activation of islet-specific $\mathrm{T}$ cells and reduced the incidence of diabetes in NOD mice (Griffin et al. 2000; 
Fife et al. 2006a). Of note, CTLA-4 is also critical for the function of regulatory T cells (Tregs) (Fife and Bluestone 2008; Wing et al. 2008; Bour-Jordan and Bluestone 2009), but the sc $\alpha$ CTLA-4 Tg protected Treg-deficient NODB7-1/2KO mice from diabetes as well, showing an autoreactive conventional T-cell intrinsic effect (Fife et al. 2006a). The absence of PD-1 signals in NOD mice deficient for PD-1 or its ligands, PD-L1 and PD-L2, results in accelerated diabetes (Fife et al. 2006b). Importantly, CTLA4 and PD-1 appear to have complementary but nonoverlapping roles in diabetes tolerance (Fife and Bluestone 2008). Indeed, CTLA-4 blockade is most efficient in early stages of the autoimmune response in the pancreatic LN whereas expression of PD-L1 in the peripheral tissue is critical for the tolerogenic role of PD-1 (Luhder et al. 1998; Walker et al. 2002; Keir et al. 2006). In a model of tolerance induced by antigen-coupled ethylcarbodiimide (ECDI)-fixed spleen cells, both CTLA-4 and $\mathrm{PD}-1$ were important in induction of tolerance, but only PD-1 controlled maintenance of the tolerant state (Fife et al. 2006b). This paradigm was reinforced by the predominant role of $\mathrm{PD}-\mathrm{L} 1$, rather than $\mathrm{PD}-\mathrm{L} 2$, in the tolerogenic role of PD-1 in diabetes, which correlates with the widespread expression of PD-L1, including in pancreatic islets, as compared with the limited expression of PD-L2 on DCs and monocytes (Fife et al. 2006b; Keir et al. 2006).

Potential defects in the CTLA-4 and/or PD-1 pathways in T1D patients are suggested by the association of polymorphisms in both genes with susceptibility to disease (Nielsen et al. 2003; Ueda et al. 2003). Additionally, lower expression levels of PD-1 was found on peripheral blood-derived $\mathrm{CD}^{+}{ }^{+} \mathrm{T}$ cells from a small group of T1D patients as compared with controls (Tsutsumi et al. 2006). The CTLA-4 gene has several splice variants, most notably a ligand-independent isoform (liCTLA-4) and a soluble secreted isoform (sCTLA-4) found in mice and humans. Several autoimmune diseases, including T1D, have been associated with the differential expression of splice variants. In NOD mice, lower expression of the liCTLA-4 isoform caused by a single nucleotide polymorphism in exon 2 has been identified as the basis for one of the genetic loci, Idd5.1, that has been mapped, genetically to be associated with disease susceptibility in mice (Araki et al. 2009). In fact, increasing expression of liCTLA-4 in Tg mice reduced the incidence of diabetes in NOD mice (Araki et al. 2009). The respective role and mechanisms of full-length and ligand-independent CTLA-4 isoforms in peripheral tolerance are still under discussion, but it is conceivable that they differentially control homeostatic proliferation versus tissue-specific T-cell responses (Bour-Jordan et al. 2011).

Finally, other negative regulators of T-cell function have been described and could be involved in maintaining tolerance to pancreatic islets. B- and T-lymphocyte attenuator (BTLA) is a negative regulator of T-cell activation that is predominantly expressed on recently activated $\mathrm{T}$ cells and differentiated Th1 cells (Watanabe et al. 2003). Islet-specific TCR-Tg CD8 ${ }^{+} \mathrm{T}$ cells deficient for BTLA showed increased accumulation in pancreatic LN and induced diabetes more efficiently than wild-type (WT) T cells (Liu et al. 2009). Additionally, treatment with a nonblocking anti-BTLA mAb resulted in $\mathrm{CD}^{+}{ }^{+}$T-cell and $\mathrm{B}$-cell depletion and decreased diabetes incidence in NOD mice (Truong et al. 2009). Tim-3 (T-cell immunoglobulin domain, mucin domain-3) is another inhibitory molecule of T-cell function preferentially expressed on Th1 cells (Monney et al. 2002). Blockade of interactions between Tim-3 and Tim-3L accelerated diabetes in NOD mice (Sanchez-Fueyo et al. 2003). Although their mode of action remains to be fully elucidated, both BTLA and Tim-3 appear to affect tolerance by altering the relative number and/or functional efficiency of Th1, Th2, and Treg subsets (Sanchez-Fueyo et al. 2003; Liu et al. 2009; Truong et al. 2009).

\section{EXTRINSIC CONTROL OF PATHOGENESIS}

During the last decade, a wealth of data has identified $\mathrm{CD}^{+}{ }^{+} \mathrm{CD} 25^{+}$Foxp $^{+}$regulatory $\mathrm{T}$ cells (Tregs) as a critical cell population for the extrinsic control of peripheral tolerance. In scurfy mice and immune dysregulation, polyendocrinopathy enteropathy X-linked (IPEX) syndrome 


\section{L.T. Jeker et al}

IPEX patients, genetic deficiency in the Treg lineage marker Foxp3 rapidly results in widespread autoimmunity and a fatal LPD (Bennett et al. 2001; Fontenot et al. 2003; Hori et al. 2003; Khattri et al. 2003). Foxp3 remains critical throughout life to maintain the Treg population and prevent autoimmunity (Kim et al. 2007). In NOD mice, depletion of CD $4{ }^{+} \mathrm{CD} 25^{+}$Tregs greatly accelerates the development of diabetes, and T1D is a hallmark of the clinical triad in infants with IPEX syndrome (Salomon et al. 2000). Similarly, affecting the homeostasis of Tregs by targeting signals necessary for their development or survival, such as IL-2 or CD28, exacerbates diabetes and other underlying autoimmune diseases in NOD mice (Salomon et al. 2000; Setoguchi et al. 2005; Meagher et al. 2008). NOD mice deficient for Foxp3 develop the same LPD as in other strains (Chen et al. 2005), but conditional depletion of Foxp3-expressing Treg in BDC2.5 TCR-Tg mice resulted in fulminant diabetes within 3 days (Feuerer et al. 2009). Thus, peripheral tolerance in NOD mice is dependent on the balance of effector and regulatory T cells (Fig. 2) (Bour-Jordan et al. 2004a).

Pathogenic T cells undergo qualitative changes during the progression to diabetes that render them less susceptible to regulation by Tregs (You et al. 2005; D’Alise et al. 2008). Counterintuitively, the percentage of Tregs in pancreatic LN increased with age in NOD mice (Tang et al. 2008). However, in the pancreatic tissue, there was an inverse correlation between the frequency of Tregs and the size of the infiltrate in NOD mice, suggesting a local deficiency in Treg-mediated immunoregulation (Tang et al. 2008). Additionally, islet-infiltrating Tregs displayed low levels of the Interleukin-2 receptor alpha (CD25), Foxp3, and the survival factor $\mathrm{Bcl}-2$, which levels of expression are all promoted by IL-2 signaling. This, in turn, could affect the survival and suppressive function of Tregs in pancreatic islets (Malek et al. 2002; Fontenot et al. 2005; Barron et al. 2010). Importantly, treatment with low-dose IL-2 preferentially targets regulatory rather than effector $\mathrm{T}$ cells, restores Treg expression of CD25 and Foxp3, and can prevent or even reverse diabetes in NOD mice (Tang et al. 2008; Grinberg-Bleyer et al. 2010). In this regard, the IL-2 gene was identified as the likely candidate for susceptibility locus Idd3 in NOD mice, and polymorphisms in the IL-2 gene result in lower levels of IL-2 production (Wicker et al. 1994; Lyons et al. 2000; Yamanouchi et al. 2007). Thus, defective IL-2 production by Teff in pancreatic islets could be responsible for the low CD25 expression and poor survival of Tregs in the tissue.

Of note, genome wide association studies have identified polymorphisms in the IL-2, CD25 and PTPN22 genes associated with susceptibility to T1D (Bottini et al. 2004; Vella et al. 2005; Todd et al. 2007). Tregs from T1D patients express normal levels of CD25 but present defects in IL-2 receptor signaling, including inferior phosphorylation of STAT5, which may result in impaired Foxp3 expression (Long et al. 2010). The percentage of Tregs in the peripheral blood is normal in T1D patients (Liu et al. 2006) and Tregs from T1D patients and control subjects were found to be equally capable of suppressing T-cell proliferation in vitro (Putnam et al. 2009). However, like in NOD mice, polyclonal Treg numbers at the site of inflammation might be dysregulated even when Treg frequencies in peripheral blood are normal. In addition, a reduction of the most potent antigen-specific Treg might be missed by measuring Treg numbers solely based on CD25 and Foxp3. Quantitation of Treg to Teff ratios in human pancreas is challenging not only because of difficulties in getting access to recent onset T1D pancreata but also because islet destruction can be limited to certain lobules whereas others remain intact (Bluestone et al. 2010). Other studies have described defects in in vitro suppression that may relate to an increased resistance of Teff to suppression (Schneider et al. 2008), as in NOD mice. Moreover, the function of human Tregs is commonly assessed by in vitro suppression assays. However, genetic studies in mice have clearly established that Treg dysfunction that leads to very severe spontaneous LPD in vivo can go along with normal in vitro suppressive capacity (Liston et al. 2008; Zhou et al. 2008; Lu et al. 2010). Thus, while impaired in vitro suppression suggests a Treg defect, 


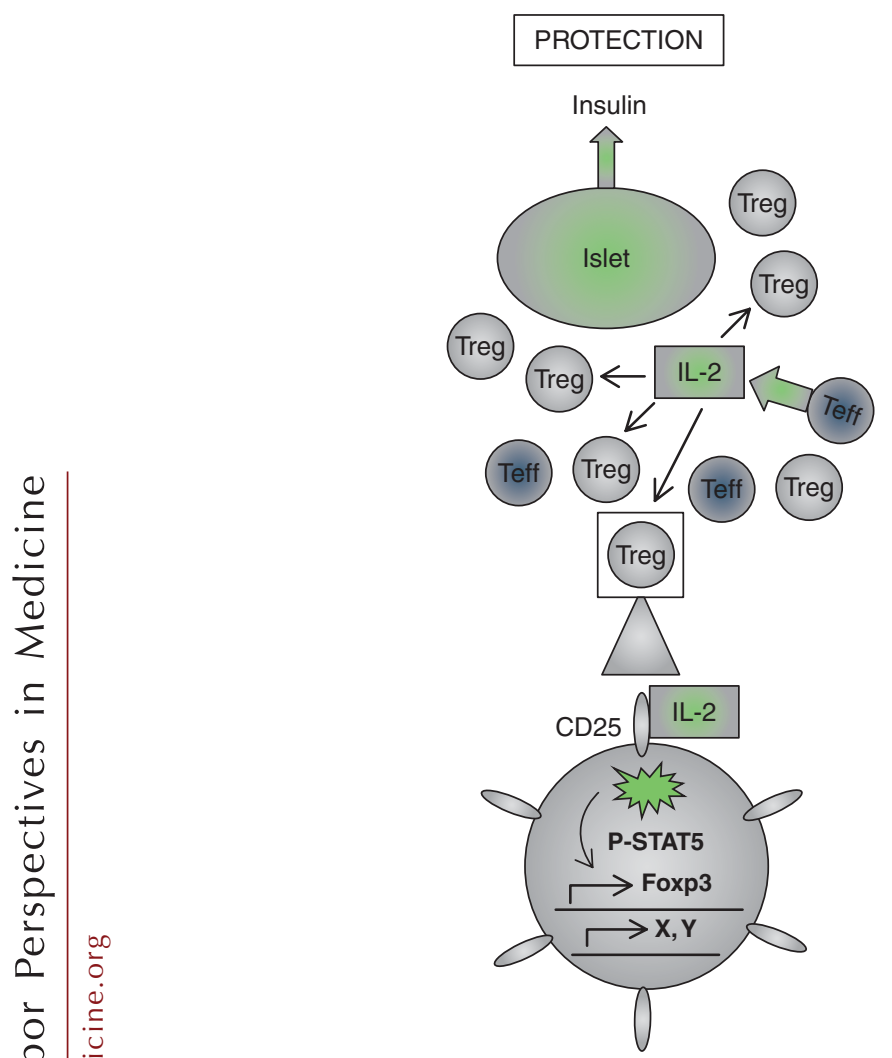

\section{DESTRUCTION}

Figure 2. Role of the IL-2 pathway and the Teff/Treg balance in the tissue. This figure depicts how the balance of Teff and Tregs and their complex interactions, notably the IL-2 pathway, results in destruction or protection of pancreatic islets (see text for details). A magnified view of the outcome of IL-2 signaling in Tregs is shown at the bottom. In islets or individuals in which protection is dominant (left panel), the Teff/Treg ratio is skewed toward regulation; Teff secrete significant amounts of IL-2; IL-2 binds to the IL-2 receptor, expressed at high levels on Tregs, which triggers a robust IL-2 signaling, including high levels of STAT5 phosphorylation; this, in turn, ultimately results in the transcription of many IL-2 dependent genes, including Foxp3, which are important to maintain their survival at the tissue site. In individuals genetically susceptible to diabetes (right panel), the survival of Tregs in the islets is compromised and they cannot control the Teff pathogenic response; the half-life or levels of secretion of IL-2 by Teff is deficient; IL-2 signaling is reduced because of lower expression of the IL-2 receptor and/or lower STAT5 phosphorylation; this results in altered transcription of IL-2-dependent genes and poor survival of Tregs in the islets.

normal in vitro suppressive capacity does not equal normal Treg function. It therefore remains to be determined if T1D Tregs are fully functional and alternative human Treg assays are needed.

Recently, the plasticity of nTregs as it relates to the stability of the Foxp3 lineage marker has been evaluated in elaborate reporter mouse models. A significant subset of $\mathrm{CD} 4^{+} \mathrm{T}$ cells was found to show unstable Foxp3 expression (exFoxp3 cells) and produce IFN- $\gamma$ and IL-17
(Zhou et al. 2009b). exFoxp3 cells were enriched in inflammatory conditions and/or autoimmunity-prone backgrounds such as the NOD mouse. Importantly, self-reactive exFoxp3 cells were pathogenic and could induce autoimmunity on adoptive transfer in vivo. These cells were likely derived both from unstable Tregs and from Teff that had transiently up-regulated Foxp3, a result that has implications in humans in which most Teff transiently express Foxp3 on activation. In this regard, the frequency of Tregs 


\section{L.T. Jeker et al}

producing proinflammatory cytokines such as IFN- $\gamma$ or IL-17 is elevated in T1D patients $(\mathrm{Mc}-$ Clymont et al. 2011). These Foxp $3^{+}$IFN- $\gamma^{+}$ Tregs are suppressive in vitro but display phenotypic and epigenetic characteristics of adaptive Tregs, such as low expression of Helios and overall methylation of the TSDR at the Foxp3 locus, raising the possibility that they may not be as stable as natural (e.g., thymus-derived) Tregs. Thus, although the stability of Tregs is still controversial (Rubtsov et al. 2010; Bailey-Bucktrout et al. 2011), the prospect of unstable Tregs is clearly a topic that must be analyzed further in view of the current development of Treg-based clinical trials in autoimmunity and transplantation.

Despite all the advances in Treg biology, the suppressive mechanisms employed by Tregs are still a matter of debate. Among the mechanisms that have been proposed, Tregs can directly suppress Teff cells in a contact-dependent manner, especially in vitro, produce immunoregulatory cytokines such as IL-10 and TGF- $\beta$, and alter antigen presentation by dendritic cells and/ or drive them to produce suppressive factors such IDO (Tang and Bluestone 2008). It is possible that the identification of these different pathways reflects the suppression by Tregs of immune responses taking place in different tissues with distinct dynamics and unique immunological environments. In this regard, it has been postulated that the transcriptional program of Tregs, and conceivably their suppression mechanism, can be tailored to the nature of the effector response they regulate (Chaudhry et al. 2009; Koch et al. 2009; Zheng et al. 2009). Another confounding factor is the fact that the "regulatory $\mathrm{T}$ cell" label can be comprised of functionally distinct subsets. For example, besides thymically-derived $\mathrm{CD}^{+}$ Foxp $^{+}$natural Tregs (nTregs), $\mathrm{CD}^{+}{ }^{+}$Foxp $^{+}$ adaptive Tregs (aTregs) (induced from $\mathrm{CD} 4^{+}$ CD25- cells), TGF- $\beta$-dependent Th3 cells, IL10-dependent $\operatorname{Tr} 1$ cells, and $\mathrm{CD}^{+}{ }^{+}$Tregs have been described in mice and humans and could be involved in different models of tolerance (Bisikirska et al. 2005; Roncarolo et al. 2006; Weiner et al. 2011). In the NOD mouse, Tregs have been shown to interact with DCs rather than autoreactive $\mathrm{T}$ cells and alter presentation of self-antigens in pancreatic LNs (Tang et al 2006). Ablation of Tregs acutely triggered diabetes in BDC2.5 TCR-Tg mice. Intriguingly, the immunoregulatory control exerted by Tregs in the pancreatic islets appeared to largely target natural killer (NK) cells and their production of IFN- $\gamma$, which subsequently licensed autoreactive $\mathrm{CD}^{+}$Teff for tissue destruction (Feuerer et al. 2009). Different subsets of regulatory $\mathrm{T}$ cells producing IL-10 or TGF- $\beta$ have been found in unmanipulated NOD mice or after tolerogenic treatments such as anti-CD3 therapy (You et al. 2004, 2007; Bresson et al. 2006; Weiner et al. 2011). In humans, T cells stimulated with self-peptides isolated from a susceptibility MHC allele were skewed toward proinflammatory cytokine production in T1D patients versus immunoregulatory IL-10 in healthy controls (Arif et al. 2004). Additionally, treatment of new-onset diabetic patients with FcR-nonbinding anti-CD3 mAbs, which led to insulin independence for over 5 years in some cases, was associated with enrichment in IL-10producing $\mathrm{CD}^{+} \mathrm{T}$ cells and in $\mathrm{CD} 8^{+} \mathrm{CD} 25^{+}$ Foxp $3^{+}$regulatory T cells (Herold et al. 2003, 2009; Bisikirska et al. 2005). Thus, Treg play a crucial role preventing T1D through a multitude of effector mechanisms and subtypes.

\section{INFLUENCE OF PATHOGEN EXPOSURE AND THE COMMENSAL FLORA}

Despite having a well-documented genetic component, it has also been recognized that the environment plays an important role in the triggering of or protection from T1D. The exact nature of environmental factors influencing the development of T1D in humans is largely speculative, but it is generally accepted that frequent exposure to pathogens inversely correlates with the incidence of disease, a phenomenon known as the "hygiene hypothesis." Similarly, diabetes in NOD mice is influenced by the cleanliness of the facility housing the mouse colony, with the incidence of disease higher in NOD mice housed in SPF facilities by comparison with "dirty" facilities (Pozzilli et al. 1993; Okada et al. 2010). Diabetes in NOD mice is also prevented by administration of complete Freund's 
Breakdown in Peripheral Tolerance in T1D

adjuvant, which is essentially an emulsion of mycobacteria (Sadelain et al. 1990; McInerney et al. 1991). The mechanisms involved are complex, but among pathways that sense and recognize foreign pathogens, receptors for pathogenassociated molecular patterns (PAMPs), most notably toll-like receptors (TLRs), are likely to play a significant role.

Most TLRs use the adapter protein MyD88 for signal transduction. MyD88 affects antigen presentation by both DCs and B cells and promotes T-cell proliferation and survival in a $\mathrm{T}$ cell-intrinsic manner (Gelman et al. 2006; Hou et al. 2008, 2011; Rahman et al. 2008). Thus, deficiency in MyD88 leads to a profound defect in $\mathrm{T}$ cell and $\mathrm{T}$ cell-dependent responses. It was recently shown that MyD88 influences the composition of the commensal flora in the gut of NOD mice, and that this in turn affects the development of diabetes (Wen et al. 2008). Indeed, NOD mice deficient for MyD88 (MyD88KO) were protected from diabetes in SPF facilities. Intriguingly, NOD-MyD88KO mice housed in germ-free facilities developed diabetes at a normal rate, but infiltration in the islets was less severe if these mice were colonized with a representative sample of gut flora from NOD mice. Protection from diabetes in SPF NODMyD88KO mice was accompanied by reduced islet infiltration. Additionally, T-cell responses to islet antigens were lower in pancreatic LN only and spleen cells from NOD-MyD88KO mice transferred diabetes in immunodeficient recipients as efficiently as NOD cells, demonstrating a local but not global tolerance to islet antigens (Wen et al. 2008). The underlying mechanisms are still unknown, but NODMyD88KO mice had a normal frequency of Tregs in pancreatic LN, and tolerance induction in this model may involve alterations of APCs and presentation of self-antigens. In this regard, the gut mucosal tissue has long been known to be a hot spot for T-cell tolerance resulting from a complex network of interactions between various cell-types, including tolerogenic CD103 ${ }^{+}$ DCs and various populations of regulatory $\mathrm{T}$ cells (Weiner 2001; Coombes et al. 2007). The oral route is a prevalent path of pathogen exposure and increased intestinal permeability has been associated with diabetes in mice and humans (Vaarala et al. 2008). Additionally, gut antigens have been shown to be presented in pancreatic LN and the immune environment in the gut can affect the presentation of islet antigens (Turley et al. 2005). Finally, oral administration of anti-CD3 mAbs ameliorates diabetes in NOD mice (Weiner et al. 2011). Taken together, these data suggest that gut antigens and the gut flora can influence the development of diabetes.

\section{EMERGING ROLE FOR MicroRNAS IN IMMUNE REGULATION}

MicroRNAs (miRNAs) are a class of nonprotein-coding RNAs that repress other genes posttranscriptionally by binding complementary mRNA sequences leading to translational inhibition and/or mRNA destabilization (Lim et al. 2005; Fabian et al. 2010; Guo et al. 2010). miRNAs are considered fine-tuners (Bartel 2009) because inhibition is moderate for most individual proteins, often less than 50\% (Baek et al. 2008; Selbach et al. 2008). Genetic loss of one allele can, however, impair immune homeostasis: PTEN or proapoptotic protein Bim heterozygous mice develop spontaneous systemic autoimmune disease (Bouillet et al. 1999; Di Cristofano et al. 1999). Importantly, B7-1 and B7-2 heterozygous NOD mice display reduced Treg numbers (Salomon et al. 2000; Bour-Jordan and Bluestone 2009). In B7-1 heterozygous mice this leads to accelerated diabetes onset compared to control mice because of a change in CD28 and/or CTLA-4 signaling (Salomon et al. 2000) in T cells. In contrast, B7-2 heterozygous NOD mice are protected from disease, despite the reduced Treg numbers. Further analysis revealed that reduction of B7-1 preferentially affected Treg numbers whereas reduction of B7-2 preferentially reduced Teff numbers (Bour-Jordan et al. 2004). Thus, gradual effects selectively affect the Teff/Treg balance (Bour-Jordan and Bluestone 2009). These examples illustrate how sensitive the immune system can be to minor changes in protein concentrations. miRNAs are likely involved in the tight regulation of immunologically relevant protein 


\section{L.T. Jeker et al}

concentrations and haploinsufficient genes are likely key miRNA targets (Xiao and Rajewsky 2009; Jeker and Bluestone 2010). Finally, miRNAs target hundreds of genes simultaneously (Lim et al. 2005) and often several members of the same biochemical pathway are targeted by the same miRNA resulting in a cumulative inhibition. In summary, minor changes in protein concentrations can have dramatic effects and can predispose to autoimmune disease.

Cell-type-specific ablation of key proteins required for proper miRNA biogenesis (Dicer, Drosha or DGCR8) has shown a critical role for miRNAs in all immune cell types tested so far (Cobb et al. 2005, 2006; Chong et al. 2008; Koralov et al. 2008; Liston et al. 2008; Zhou et al. 2008; Bezman et al. 2010). Decreased proliferation and survival are commonly found. Deletion of Dicer in all T cells leads to a spontaneous multiorgan autoimmune disease in about half of the affected mice (Cobb et al. 2006). $\mathrm{CD}^{+}{ }^{+}$Foxp $3^{+}$regulatory T-cell-specific miRNA ablation, leads to a much more aggressive disease closely resembling Foxp3-deficient scurfy disease in which Treg are entirely dysfunctional (Chong et al. 2008; Liston et al. 2008; Zhou et al. 2008).

Despite these clear demonstrations of an essential nonredundant role for miRNAs in immune regulation our understanding of the role of individual miRNAs in immune regulation is fairly limited. Some of the best studied miRNAs to date are miR-155 and miR-146. Mice deficient for miR-155 display a complex phenotype of immunodeficiency and likely increased autoimmunity caused by dysfunction of DC, B, and T cells (Rodriguez et al. 2007; Thai et al. 2007). Simultaneous immunodeficiency and autoimmune disease might be a consequence of miR-155 having cell-type-dependent opposing functions in immune regulation. Surprisingly, despite bic/miR-155 being a direct Foxp3 target leading to significant enrichment in Treg expression (Gavin et al. 2007; Marson et al. 2007; Zheng et al. 2007) Treg function is largely preserved in the absence of miR-155 (Kohlhaas et al. 2009; Lu et al. 2009). Nevertheless, miR-155 is required for normal numbers of Treg under homeostatic conditions, possibly in part because of impaired proliferation and IL-2 signaling in the absence of miR-155 ( $\mathrm{Lu}$ et al. 2009). Of note, Dicer-deficient Treg lose their lineage defining transcription factor Foxp3 (Zhou et al. 2008). Given the important role of IL-2 for the maintenance of high Foxp3 and CD25 expression and Treg function and stability in inflamed pancreatic islets (Tang et al. 2008; Zhou et al. 2009b) it is conceivable that miR-155 might play a role in the prevention of T1D through stabilizing Treg. On the other hand, miR-155-deficient mice are resistant to experimental autoimmune encephalitis (EAE), a model of multiple sclerosis (O'Connell et al. 2010) caused by defects in T cells and DCs. Thus, miR-155 plays opposing functions in immune regulation.

In contrast, miR-146a was dampening immune responses in all immune cell types analyzed to date. miR-146a-deficient mice spontaneously develop an inflammatory syndrome of myeloproliferation and autoimmunity likely due to a reduced negative feedback loop in various myeloid cells and T cells (Taganov et al. 2006). In addition, miR-146a is enriched in Treg and is required under stress conditions for proper Treg suppression of Th1 responses ( $\mathrm{Lu}$ et al. 2010). Thus, miR-146a seems to dampen immune responses through negative regulation of proinflammatory cell types and enhancement of suppressive Treg. If, and to what degree, miR-146a prevents T1D by repressing IFN- $\gamma$ secretion by autoreactive Teffector cells and/or enhancing Treg function to suppress pancreatic inflammation will need careful analysis. Such studies might shed new light onto the controversial role of IFN- $\gamma$ in the pathogenesis of T1D.

With miRNAs predicted to be targeting 50\% of all protein coding genes, there is no doubt that miRNAs are involved in the prevention of T1D. Studies investigating a causative involvement of miRNAs in T1D are currently lacking. Treg from T1D patients display altered miRNA expression compared to Treg from healthy controls (Hezova et al. 2010) and miR10a has been shown to be differentially expressed in regulatory $\mathrm{T}$ cells from diabetes-prone NOD mice (LT Jeker, Y Zhou, and KGershberg, submitted). The importance of miRNAs for the control of immune regulation suggests that dysregulation 
of miRNAs or mutations in binding sites of miRNA targets may shift the balance between immunity and immune regulation. This may happen in various cell types and may influence multiple immunologic checkpoints of tolerance. A better understanding of miRNA function in the immune system in general and in T1D in particular are needed to exploit this relatively new class of genes for diagnostics and/or therapeutic approaches.

\section{THERAPEUTIC APPROACHES TO REPAIR TOLERANCE}

Many therapeutic approaches aimed at correcting some of the immunological defects described above are currently being tested in clinical trials in T1D (Bluestone et al. 2010; van Belle et al. 2011). Among these, we will focus on a few selected immunotherapies, which attempt restoring tolerance rather than controlling inflammation and/or improving islet function. A few preventive trials have been or are being performed in at-risk individuals, usually identified as first-degree relatives of T1D patients positive for at least two autoantibody specificities against insulin, GAD or IA-2. Some prevention trials attempt to induce antigenspecific tolerance using oral or nasal administration of insulin, which is believed to be a major and early auto-antigen in T1D (Zhang et al. 2008). So far, preventive approaches have yielded disappointing results with little to no efficacy in delaying or preventing T1D (Chaillous et al. 2000; DPT-1-Diabetes-Study-Group 2002; Barker et al. 2007; Nanto-Salonen et al. 2008). Many intervention clinical trials are performed in new-onset diabetic patients during the first few months after clinical diagnosis. This phase of reduced insulin dependency reflects a certain level of islet preservation and can last from a few months to a couple of years in some patients. Other trials enroll patients completely dependent on insulin therapy but must be accompanied by islet replacement strategies such as allogeneic pancreatic islet transplantation (Alejandro et al. 2008; Posselt et al. 2010).

Recently, clinical trials of Fc receptor nonbinding (FNB) anti-CD3 mAbs have proved to be one of the most successful immunotherapies in T1D to date (Herold et al. 2002; Keymeulen et al. 2005). FNB anti-CD3 reagents provide a suboptimal TCR signal to T cells and have powerful tolerogenic properties in animal models (Smith et al. 1997), as evidenced by the reversal of new-onset diabetes in NOD mice (Chatenoud et al. 1994, 1997). Remarkably, a shortcourse treatment with FNB anti-CD3 mAbs (teplizumab) led to preserved islet function for up to five years in new-onset T1D patients (Herold et al. 2005, 2009). In mice, the tolerogenic effects of FNB anti-CD3 mAbs may rely on the preferential depletion of pathogenic effector T cells whereas Tregs are relatively resistant to depletion (Smith et al. 1998; Penaranda et al. 2011). As a result, the balance of Teff to Tregs is reset to favor immunoregulation because of a higher frequency (if not absolute number) of Tregs (Belghith et al. 2003; Bresson et al. 2006). In humans, FNB anti-CD3 mAbs do not induce massive $\mathrm{T}$-cell depletion but treatment in T1D patients induces a population of regulatory T cells (Bisikirska et al. 2005). Another approach targeting $\mathrm{T}$ cells at the population level is using antilymphocyte serum (ALS) or antithymocyte globulin (ATG), two related polyclonal anti-T-cell reagents that induce a profound but transient T-cell depletion. ATG/ ALS could induce long-term remission in newonset diabetic NOD mice via mechanisms that may include preferential repopulation of the T-cell compartment by Tregs (Ogawa et al. 2006; Simon et al. 2008). Treatment of T1D patients with ATG yielded promising results in a small study but side effects associated with cytokine release syndrome were observed (Saudek et al. 2004). An immune tolerance network (ITN)sponsored phase II clinical trial using a different dosing regimen of ATG has been initiated in a larger number of patients. The efficacy of both ATG and FNB anti-CD3 mAbs in new-onset diabetic NOD mice was enhanced in combination with exendin-4, a reagent that improved the functional recovery of residual islets (Ogawa et al. 2004; Sherry et al. 2007). Concomitant targeting of the autoimmune response and the islet tissue may be important in achieving long-term tolerance and restoration of $\beta$-cell 


\section{L.T. Jeker et al}

function in T1D patients. Alternatively, combination therapies that synergistically alter immune responses are being considered to maximize the tolerogenic outcome (Matthews et al 2010). For example, a phase I trial supported by the ITN and combining IL-2 and rapamycin is currently underway in T1D patients, with the rationale that both reagents will synergize to delete autoreactive effector $\mathrm{T}$ cells and favor the expansion or survival of Tregs.

Antigen-specific therapies are an attractive alternative because the expectation is that they could help restore tolerance to islet antigens without inducing global immunosuppression. Antigen-specific clinical trials have been targeting T-cell responses either to known major auto-antigens in T1D (GAD, insulin) or to isletderived peptides eluted from human MHC class II molecules (Ergun-Longmire et al. 2004; Alleva et al. 2006; Ludvigsson et al. 2008, 2011; Agardh et al. 2009; Thrower et al. 2009; Walter et al. 2009; Gottlieb et al. 2010; Orban et al. 2010). Different approaches have been used, including, theoretically, favoring presentation of auto-antigens by tolerogenic APCs, altering the TCR recognition of its cognate antigen in autoreactive cells and/or the skewing of the T-cell response from pathogenic Th1 cells to protective Th2 cells. So far, some phase I and II clinical trials have shown efficacy in maintaining C-peptide levels and inducing favorable immune parameters such as decreased Th1/Th2 ratio and increased Tregs and TGF- $\beta$ (Agardh et al. 2005; Alleva et al. 2006; Ludvigsson 2009; Orban et al. 2010; Ludvigsson et al. 2011). Currently available data on the outcome on disease progression have shown either no effect or encouraging results such as improved C-peptide and $\mathrm{HbA1C}$ levels and decreased insulin need, and the clinical benefits were but short-lived. Although these results are clearly less dramatic than in animal models, additional studies with higher numbers of patients and different reagents, doses and/or timing of administration will determine whether antigen-specific therapies could be part of the therapeutic arsenal against T1D, alone or in combination with other immunomodulating agents or treatment targeting $\beta$-cell survival and function.
Cellular therapy is currently being actively pursued. In preclinical animal models, Tregs have shown a great degree of efficacy in both preventive and curative approaches in many models of autoimmune disease and transplantation. A JDRF-sponsored phase I clinical trial was recently initiated to evaluate autologous Tregs expanded in vitro (Putnam et al. 2009). The rationale for this approach is based on animal models demonstrating an imbalance between Teff and Tregs in autoimmune diabetes and the demonstration that expanded Tregs can suppress disease in NOD mice (Tang et al. 2004). Treg therapy holds great promises in many human diseases but significant challenges are present and will need to be dealt with, including the absence of lineage-specific surface marker that can be used to isolate Tregs in humans; the possibility that effective therapy will require either high numbers of polyclonal Tregs or antigen-specific Tregs, which will both require significant technical prowess from the clinical trial team; and, as mentioned above, the possible occurrence of unstable Tregs that may affect the efficacy of Tregs as immunotherapy and/or the initial disease. Recent trials of autologous nonmyeloablative hematopoietic stem cell transplantation have shown promising results in a small number of new-onset T1D patients with preservation of C-peptide levels and prolonged insulin independence in many patients (Voltarelli et al. 2007; Couri et al. 2009). Finally, spleen cells incubated with a selfantigen or peptide and chemically fixed with ECDI have potent tolerogenic properties in mouse models of autoimmunity (Miller et al. 2007). Antigen-coupled ECDI-treated spleen cells can reverse diabetes in NOD mice and prevent allogeneic islet rejection through intrinsic control of autoreactive $\mathrm{T}$ cells by the PD-1 pathway and extrinsic regulation by Tregs (Fife et al. 2006b; Luo et al. 2008). A clinical trial of insulin-coupled autologous PBMCs is currently being developed by the ITN. Finally, other cell therapies are being tested including cord blood and mesenchymal stem cells (Haller et al. 2010).

Briefly, many other clinical trials are being conducted to restore tolerance in T1D patients. 
Costimulation blockade using CTLA-4Ig (abatacept or belatacept) was recently shown in a phase II clinical trial in T1D patients and after islet transplantation to slow progression of the disease and block rejection, respectively (Orban et al. 2011; Posselt et al. 2010). Of note, like other immunotherapies targeting effector $\mathrm{T}$ cells, CTLA-4Ig was already under clinical development at the time Tregs became prominent. The discovery that CD28 signals were critical for Treg homeostasis (Salomon et al. 2000) raised the concern that CTLA-4Ig treatment may deplete the Treg population and have unintended consequences on disease incidence. A recent trial in renal transplantation reported that belatacept did not reduce the frequency of Tregs in the peripheral blood or kidney transplant (Bluestone et al. 2008). However, it will be important to perform immune in addition to clinical monitoring in these clinical trials to determine the outcome of a given reagent at a given dose on effector versus regulatory $\mathrm{T}$ cells. In view of the "hygiene hypothesis" and the dramatic tolerogenic effect of CFA in NOD mice, several studies have been carried out in humans using agents that activate the innate immune system. Although previous trials of BCG (Bacillus Calmette-Guerin) administration had no effect on T1D (Elliott et al. 1998; Allen et al. 1999), there are ongoing clinical efforts underway to test the administration of BCG and other toll-like receptor ligand to activate this innate arm of the immune response in the hopes of moderating disease progression.

\section{CONCLUDING REMARKS}

Considerable strides have been made during the last two decades in the understanding of the mechanisms of peripheral tolerance that are affected in autoimmune diabetes. As described in this article, many steps in the stimulation, function and regulation of autoreactive T cells can be impaired in genetically-susceptible individuals and as a consequence of a given environment. The recent and ongoing discovery of the role of microRNAs and other innovative strategies in fine-tuning immune responses, cellular interactions and decision-taking in the immune system will likely provide important insights in the breakdown of peripheral tolerance in T1D and other autoimmune diseases in the near future. In fact, while tolerogenic immunotherapies have been and are currently being developed with sometimes disappointing results and/or unacceptable side effects, it is conceivable that the microRNA field will produce the next breakthroughs in therapeutic approaches in T1D and bring forward innovative strategies aiming at restoring tolerance by producing incremental or concomitant minute changes at the system level.

\section{ACKNOWLEDGMENTS}

The authors wish to thank the members (past and present) of the Bluestone laboratory who have contributed to the studies highlighted in this article. In addition, the authors thank the funders, including NIAID, NIDDK, JDRF, the Swiss National Science Foundation, the Brehm Coalition, and the ADA as well as several companies (Pfizer and Becton-Dickenson), who have made this research possible.

\section{REFERENCES}

Agardh CD, Cilio CM, Lethagen A, Lynch K, Leslie RD, Palmer M, Harris RA, Robertson JA, Lernmark A. 2005. Clinical evidence for the safety of GAD65 immunomodulation in adult-onset autoimmune diabetes. J Diabetes Complications 19: 238-246.

Agardh CD, Lynch KF, Palmer M, Link K, Lernmark A. 2009. GAD65 vaccination: 5 years of follow-up in a randomised dose-escalating study in adult-onset autoimmune diabetes. Diabetologia 52: 1363-1368.

Alejandro R, Barton FB, Hering BJ, Wease S. 2008. 2008 Update from the Collaborative Islet Transplant Registry. Transplantation 86: 1783-1788.

Allen HF, Klingensmith GJ, Jensen P, Simoes E, Hayward A, Chase HP. 1999. Effect of Bacillus Calmette-Guerin vaccination on new-onset type 1 diabetes. A randomized clinical study. Diabetes Care 22: 1703-1707.

Alleva DG, Maki RA, Putnam AL, Robinson JM, Kipnes MS, Dandona P, Marks JB, Simmons DL, Greenbaum CJ, Jimenez RG, et al. 2006. Immunomodulation in type 1 diabetes by NBI-6024, an altered peptide ligand of the insulin B epitope. Scand J Immunol 63: 59-69.

Amrani A, Verdaguer J, Serra P, Tafuro S, Tan R, Santamaria P. 2000. Progression of autoimmune diabetes driven by avidity maturation of a T-cell population. Nature 406: 739-742.

Anderson MS, Bluestone JA. 2005. The NOD mouse: A model of immune dysregulation. Annu Rev Immunol 23: 447-485. 
L.T. Jeker et al

Araki M, Chung D, Liu S, Rainbow DB, Chamberlain G Garner V, Hunter KM, Vijayakrishnan L, Peterson LB, Oukka M, et al. 2009. Genetic evidence that the differential expression of the ligand-independent isoform of CTLA- 4 is the molecular basis of the Idd5.1 type 1 diabetes region in nonobese diabetic mice. J Immunol 183: 5146-5157.

Arif S, Tree TI, Astill TP, Tremble JM, Bishop AJ, Dayan CM, Roep BO, Peakman M. 2004. Autoreactive T cell responses show proinflammatory polarization in diabetes but a regulatory phenotype in health. J Clin Invest 113: $451-463$.

Ausubel LJ, Chodos A, Bekarian N, Abbas AK, Walker LS. 2002. Functional tolerance is maintained despite proliferation of CD4 T cells after encounter with tissue-derived antigen. Dev Immunol 9: 173-176.

Baek D, Villen J, Shin C, Camargo FD, Gygi SP, Bartel DP. 2008. The impact of microRNAs on protein output. $\mathrm{Na}$ ture 455: 64-71.

Bailey-Bucktrout SL, Bluestone JA. 2011. Regulatory T cells: Stability revisited. Trends Immunol 32: 301-306.

Barker JM, McFann KK, Orban T. 2007. Effect of oral insulin on insulin autoantibody levels in the Diabetes Prevention Trial Type 1 oral insulin study. Diabetologia 50: 16031606.

Barron L, Dooms H, Hoyer KK, Kuswanto W, Hofmann J, O'Gorman WE, Abbas AK. 2010. Cutting edge: Mechanisms of IL-2-dependent maintenance of functional regulatory T cells. J Immunol 185: 6426-6430.

Bartel DP. 2009. MicroRNAs: Target recognition and regulatory functions. Cell 136: 215-233.

Belghith M, Bluestone JA, Barriot S, Megret J, Bach JF, Chatenoud L. 2003. TGF- $\beta$-dependent mechanisms mediate restoration of self-tolerance induced by antibodies to CD3 in overt autoimmune diabetes. Nat Med 9: 12021208.

Bending D, De La Pena H, Veldhoen M, Phillips JM, Uyttenhove C, Stockinger B, Cooke A. 2009. Highly purified Th17 cells from BDC2.5NOD mice convert into Th1-like cells in NOD/SCID recipient mice. J Clin Invest 119: 565-572.

Bennett CL, Christie J, Ramsdell F, Brunkow ME, Ferguson PJ, Whitesell L, Kelly TE, Saulsbury FT, Chance PF, Ochs HD. 2001. The immune dysregulation, polyendocrinopathy, enteropathy, X-linked syndrome (IPEX) is caused by mutations of FOXP3. Nat Genet 27: 20-21.

Bezman NA, Cedars E, Steiner DF, Blelloch R, Hesslein DG, Lanier LL. 2010. Distinct requirements of microRNAs in NK cell activation, survival, and function. J Immunol 185: 3835-3846.

Bisikirska B, Colgan J, Luban J, Bluestone JA, Herold KC 2005. TCR stimulation with modified anti-CD3 mAb expands $\mathrm{CD} 8{ }^{+} \mathrm{T}$ cell population and induces $\mathrm{CD} 8{ }^{+} \mathrm{CD} 25^{+}$ Tregs. J Clin Invest 115: 2904-2913.

Bluestone JA, Liu W, Yabu JM, Laszik ZG, Putnam A, Belingheri M, Gross DM, Townsend RM, Vincenti F. 2008. The effect of costimulatory and interleukin 2 receptor blockade on regulatory $\mathrm{T}$ cells in renal transplantation. Am Transplant 8: 2086-2096.

Bluestone JA, Herold K, Eisenbarth G. 2010. Genetics, pathogenesis and clinical interventions in type 1 diabetes. Nature 464: 1293-1300.
Boldin MP, Taganov KD, Rao DS, Yang L, Zhao JL, Kalwani M, Garcia-Flores Y, Luong M, Devrekanli A, Xu J, et al. 2011. miR-146a is a significant brake on autoimmunity, myeloproliferation, and cancer in mice. J Exp Med 208: 1189-1201.

Bottini N, Musumeci L, Alonso A, Rahmouni S, Nika K, Rostamkhani M, MacMurray J, Meloni GF, Lucarelli P, Pellecchia M, et al. 2004. A functional variant of lymphoid tyrosine phosphatase is associated with type I diabetes. Nat Genet 36: 337-338.

Bottini N, Vang T, Cucca F, Mustelin T. Role of PTPN 22 in type 1 diabetes other autoimmune diseases. 2006. Semin Immunol 18: 207-213.

Bouillet P, Metcalf D, Huang DC, Tarlinton DM, Kay TW, Kontgen F, Adams JM, Strasser A. 1999. Proapoptotic $\mathrm{Bcl}-2$ relative Bim required for certain apoptotic responses, leukocyte homeostasis, and to preclude autoimmunity. Science 286: 1735-1738.

Bour-Jordan H, Salomon BL, Thompson HL, Szot GL, Bernhard MR, Bluestone JA. 2004. Costimulation controls diabetes by altering the balance of pathogenic and regulatory T cells. J Clin Invest 114: 979-987.

Bour-Jordan H, Salomon BL, Thompson HL, Santos R, Abbas AK, Bluestone JA. 2007. Constitutive expression of B7-1 on B cells uncovers autoimmunity toward the B cell compartment in the nonobese diabetic mouse. J Immunol 179: 1004-1012.

Bour-Jordan H, Bluestone JA. 2009. Regulating the regulators: Costimulatory signals control the homeostasis and function of regulatory T cells. Immunol Rev 229: 41-66.

Bour-Jordan H, Esensten JH, Martinez-Llordella M, Penaranda C, Stumpf M, Bluestone JA. 2011. Intrinsic and extrinsic control of peripheral $\mathrm{T}$ cell tolerance by costimulatory molecules of the CD28/B7 family. Immunol Rev 241: 180-205.

Bresson D, Togher L, Rodrigo E, Chen Y, Bluestone JA, Herold KC, von Herrath M. 2006. Anti-CD3 and nasal proinsulin combination therapy enhances remission from recent-onset autoimmune diabetes by inducing Tregs. J Clin Invest 116: 1371-1381.

Chaillous L, Lefevre H, Thivolet C, Boitard C, Lahlou N, Atlan-Gepner C, Bouhanick B, Mogenet A, Nicolino M, Carel JC, et al. 2000. Oral insulin administration and residual $\beta$-cell function in recent-onset type 1 diabetes: A multicentre randomised controlled trial. Diabete Insuline Orale group. Lancet 356: 545-549.

Chatenoud L, Thervet E, Primo J, Bach JF. 1994. Anti-CD3 antibody induces long-term remission of overt autoimmunity in nonobese diabetic mice. Proc Natl Acad Sci 91: 123-127.

Chatenoud L, Primo J, Bach JF. 1997. CD3 antibody-induced dominant self tolerance in overtly diabetic NOD mice. J Immunol 158: 2947-2954.

Chaudhry A, Rudra D, Treuting P, Samstein RM, Liang Y, Kas A, Rudensky AY. 2009. CD4 ${ }^{+}$regulatory T cells control TH17 responses in a Stat3-dependent manner. Science 326: 986-991.

Chen Z, Benoist C, Mathis D. 2005. How defects in central tolerance impinge on a deficiency in regulatory $\mathrm{T}$ cells. Proc Natl Acad Sci 102: 14735-14740.

Chong MM, Rasmussen JP, Rudensky AY, Littman DR. 2008. The RNAseIII enzyme Drosha is critical in $\mathrm{T}$ cells for 
preventing lethal inflammatory disease. J Exp Med 205: 2005-2017.

Cobb BS, Nesterova TB, Thompson E, Hertweck A, O'Connor E, Godwin J, Wilson CB, Brockdorff N, Fisher AG, Smale ST, et al. 2005. T cell lineage choice and differentiation in the absence of the RNase III enzyme Dicer. J Exp Med 201: 1367-1373.

Cobb BS, Hertweck A, Smith J, O'Connor E, Graf D, Cook T, Smale ST, Sakaguchi S, Livesey FJ, Fisher AG, et al. 2006. A role for Dicer in immune regulation. J Exp Med 203: 2519-2527.

Coombes JL, Siddiqui KR, Arancibia-Carcamo CV, Hall J, Sun CM, Belkaid Y, Powrie F. 2007. A functionally specialized population of mucosal $\mathrm{CD}_{103^{+}}$DCs induces Foxp $3^{+}$regulatory T cells via a TGF- $\beta$ and retinoic aciddependent mechanism. J Exp Med 204: 1757-1764.

Couri CE, Oliveira MC, Stracieri AB, Moraes DA, Pieroni F, Barros GM, Madeira MI, Malmegrim KC, Foss-Freitas MC, Simoes BP, et al. 2009. C-peptide levels and insulin independence following autologous nonmyeloablative hematopoietic stem cell transplantation in newly diagnosed type 1 diabetes mellitus. JAMA 301: 1573-1579.

D’Alise AM, Auyeung V, Feuerer M, Nishio J, Fontenot J, Benoist C, Mathis D. 2008. The defect in T-cell regulation in NOD mice is an effect on the T-cell effectors. Proc Nat Acad Sci 105: 19857-19862.

Debray-Sachs M, Carnaud C, Boitard C, Cohen H, Gresser I, Bedossa P, Bach JF. 1991. Prevention of diabetes in NOD mice treated with antibody to murine IFN $\gamma$. J Autoimmun 4: 237-248.

Di Cristofano A, Kotsi P, Peng YF, Cordon-Cardo C, Elkon KB, Pandolfi PP. 1999. Impaired Fas response and autoimmunity in Pten ${ }^{+/-}$mice. Science 285: 2122-2125.

Dissanayake D, Gronski MA, Lin A, Elford AR, Ohashi PS. 2011. Immunological perspective of self versus tumor antigens: Insights from the RIP-gp model. Immunol Rev 241: 164-179.

DPT-Type 1 Diabetes Study Group. 2002. Effects of insulin in relatives of patients with type 1 diabetes mellitus. $N$ Engl J Med 346: 1685-1691.

Eggena MP, Walker LS, Nagabhushanam V, Barron L, Chodos A, Abbas AK. 2004. Cooperative roles of CTLA-4 and regulatory T cells in tolerance to an islet cell antigen. J Exp Med 199: 1725-1730.

Elias D, Meilin A, Ablamunits V, Birk OS, Carmi P, KonenWaisman S, Cohen IR. 1997. Hsp60 peptide therapy of NOD mouse diabetes induces a Th2 cytokine burst and downregulates autoimmunity to various $\beta$-cell antigens. Diabetes 46: 758-764.

Elliott JF, Marlin KL, Couch RM. 1998. Effect of bacille Calmette-Guerin vaccination on C-peptide secretion in children newly diagnosed with IDDM. Diabetes Care 21: 1691-1693.

Ergun-Longmire B, Marker J, Zeidler A, Rapaport R, Raskin P, Bode B, Schatz D, Vargas A, Rogers D, Schwartz S, et al. 2004. Oral insulin therapy to prevent progression of immune-mediated (type 1) diabetes. Ann NY Acad Sci 1029: $260-277$.

Esensten JH, Lee MR, Glimcher LH, Bluestone JA. 2009. T-bet-deficient NOD mice are protected from diabetes due to defects in both $\mathrm{T}$ cell and innate immune system function. J Immunol 183: 75-82.
Fabian MR, Sonenberg N, Filipowicz W. 2010. Regulation of mRNA translation and stability by microRNAs. Annu Rev Biochem 79: 351-379.

Feuerer M, Shen Y, Littman DR, Benoist C, Mathis D. 2009. How punctual ablation of regulatory $\mathrm{T}$ cells unleashes an autoimmune lesion within the pancreatic islets. Immunity 31: 654-664.

Fife BT, Bluestone JA. 2008. Control of peripheral T-cell tolerance and autoimmunity via the CTLA- 4 and PD-1 pathways. Immunol Rev 224: 166-182.

Fife BT, Griffin MD, Abbas AK, Locksley RM, Bluestone JA. 2006a. Inhibition of $T$ cell activation and autoimmune diabetes using a B cell surface-linked CTLA-4 agonist. J Clin Invest 116: 2252-2261.

Fife BT, Guleria I, Gubbels Bupp M, Eagar TN, Tang Q, Bour-Jordan H, Yagita H, Azuma M, Sayegh MH, Bluestone JA. 2006b. Insulin-induced remission in new-onset NOD mice is maintained by the PD-1-PD-L1 pathway. J Exp Med 203: 2737-2747.

Fontenot JD, Gavin MA, Rudensky AY. 2003. Foxp3 programs the development and function of $\mathrm{CD} 4^{+} \mathrm{CD} 25^{+}$ regulatory T cells. Nat Immunol 4: 330-336.

Fontenot JD, Rasmussen JP, Gavin MA, Rudensky AY. 2005. A function for interleukin 2 in Foxp3-expressing regulatory T cells. Nat Immunol 6: 1142-1151.

Fox CJ, Danska JS. 1997. IL-4 expression at the onset of islet inflammation predicts nondestructive insulitis in nonobese diabetic mice. J Immunol 158: 2414-2424.

Gardner JM, Devoss JJ, Friedman RS, Wong DJ, Tan YX, Zhou X, Johannes KP, Su MA, Chang HY, Krummel MF, et al. 2008. Deletional tolerance mediated by extrathymic Aire-expressing cells. Science 321: 843-847.

Gardner JM, Fletcher AL, Anderson MS, Turley SJ. 2009. AIRE in the thymus and beyond. Curr Opin Immunol 21: $582-589$.

Gavin MA, Rasmussen JP, Fontenot JD, Vasta V, Manganiello VC, Beavo JA, Rudensky AY. 2007. Foxp3-dependent programme of regulatory T-cell differentiation. $\mathrm{Na}$ ture 445: 771-775.

Gelman AE, LaRosa DF, Zhang J, Walsh PT, Choi Y, Sunyer JO, Turka LA. 2006. The adaptor molecule MyD88 activates PI-3 kinase signaling in $\mathrm{CD} 4^{+} \mathrm{T}$ cells and enables CpG oligodeoxynucleotide-mediated costimulation. Immunity 25: 783-793.

Gottlieb P, Colman PG, Solvason N, Otto K, Roep B, Harrison LC, Eisenbarth G, Robinson W, Utz PJ, Steinman L, Garren H, Quan J. 2010. One-year results from a phase $1 / 2$ clinical trial of BHT-3021, a DNA plasmid vaccine for type 1 diabetes (T1D). In ADA 70th Scientific Sessions. June 2010.

Griffin MD, Hong DK, Holman PO, Lee KM, Whitters MJ, O'Herrin SM, Fallarino F, Collins M, Segal DM, Gajewski TF, et al. 2000. Blockade of T cell activation using a surface-linked single-chain antibody to CTLA-4 (CD152). J Immunol 164: 4433-4442.

Grinberg-Bleyer Y, Baeyens A, You S, Elhage R, Fourcade G, Gregoire S, Cagnard N, Carpentier W, Tang Q, Bluestone J, et al. 2010. IL-2 reverses established type 1 diabetes in NOD mice by a local effect on pancreatic regulatory $\mathrm{T}$ cells. J Exp Med 20: 1871. 
L.T. Jeker et al

Gronski MA, Boulter JM, Moskophidis D, Nguyen LT, Holmberg K, Elford AR, Deenick EK, Kim HO, Penninger JM, Odermatt B, et al. 2004. TCR affinity and negative regulation limit autoimmunity. Nat Med 10: 1234-1239.

Guo H, Ingolia NT, Weissman JS, Bartel DP. 2010. Mammalian microRNAs predominantly act to decrease target mRNA levels. Nature 466: 835-840.

Haasch D, Chen YW, Reilly RM, Chiou XG, Koterski S, Smith ML, Kroeger P, McWeeny K, Halbert DN, Mollison $\mathrm{KW}$, et al. 2002. T cell activation induces a noncoding RNA transcript sensitive to inhibition by immunosuppressant drugs and encoded by the proto-oncogene, BIC. Cell Immunol 217: 78-86.

Haller MJ, Atkinson MA, Schatz DA. 2010. Efforts to prevent and halt autoimmune $\beta$ cell destruction. Endocrinol Metab Clin North Am 39: 527-539.

Hammond KJ, Poulton LD, Palmisano LJ, Silveira PA, Godfrey DI, Baxter AG. 1998. $\alpha / \beta$-T cell receptor $(\mathrm{TCR})^{+}$ $\mathrm{CD}^{-} \mathrm{CD}^{-}$(NKT) thymocytes prevent insulin-dependent diabetes mellitus in nonobese diabetic (NOD)/Lt mice by the influence of interleukin (IL)- 4 and/or IL-10. J Exp Med 187: 1047-1056.

Herold KC, Hagopian W, Auger JA, Poumian-Ruiz E, Taylor L, Donaldson D, Gitelman SE, Harlan DM, Xu D, Zivin RA, et al. 2002. Anti-CD3 monoclonal antibody in newonset type 1 diabetes mellitus. N Engl J Med 346: $1692-$ 1698.

Herold KC, Burton JB, Francois F, Poumian-Ruiz E, Glandt M, Bluestone JA. 2003. Activation of human T cells by FcR nonbinding anti-CD3 mAb, hOKT3y1(Ala-Ala). J Clin Invest 111: 409-418.

Herold KC, Gitelman SE, Masharani U, Hagopian W, Bisikirska B, Donaldson D, Rother K, Diamond B, Harlan DM, Bluestone JA. 2005. A single course of anti-CD3 monoclonal antibody hOKT3 $\gamma 1$ (Ala-Ala) results in improvement in C-peptide responses and clinical parameters for at least 2 years after onset of type 1 diabetes. Diabetes 54: 1763-1769.

Herold KC, Gitelman S, Greenbaum C, Puck J, Hagopian W, Gottlieb P, Sayre P, Bianchine P, Wong E, Seyfert-Margolis $\mathrm{V}$, et al. 2009. Treatment of patients with new onset Type 1 diabetes with a single course of anti-CD3 mAb Teplizumab preserves insulin production for up to 5 years. Clin Immunol 132: 166-173.

Hezova R, Slaby O, Faltejskova P, Mikulkova Z, Buresova I, Raja KR, Hodek J, Ovesna J, Michalek J. 2010. microRNA-342, microRNA-191 and microRNA-510 are differentially expressed in T regulatory cells of type 1 diabetic patients. Cell Immunol 260: 70-74.

Hori S, Nomura T, Sakaguchi S. 2003. Control of regulatory $\mathrm{T}$ cell development by the transcription factor Foxp3 Science 299: 1057-1061.

Hou B, Reizis B, DeFranco AL. 2008. Toll-like receptors activate innate and adaptive immunity by using dendritic cell-intrinsic and -extrinsic mechanisms. Immunity 29: 272-282.

Hou B, Saudan P, Ott G, Wheeler ML, Ji M, Kuzmich L, Lee LM, Coffman RL, Bachmann MF, Defranco AL. 2011. Selective utilization of toll-like receptor and MyD88 signaling in B cells for enhancement of the antiviral germinal center response. Immunity 34: 375-384.
Hoyne GF, Flening E, Yabas M, Teh C, Altin JA, Randall K, Thien CB, Langdon WY, Goodnow CC. 2011. Visualizing the role of Cbl-b in control of islet-reactive CD4 T cells and susceptibility to type 1 diabetes. J Immunol 186: 2024-2032.

Hultgren B, Huang X, Dybdal N, Stewart TA. 1996. Genetic absence of $\gamma$-interferon delays but does not prevent diabetes in NOD mice. Diabetes 45: 812-817.

Jeker LT, Bluestone JA. 2010. Small RNA regulators of T cellmediated autoimmunity. J Clin Immunol 30: 347-357.

Keir ME, Liang SC, Guleria I, Latchman YE, Qipo A, Albacker LA, Koulmanda M, Freeman GJ, Sayegh MH, Sharpe AH. 2006. Tissue expression of PD-L1 mediates peripheral T cell tolerance. J Exp Med 203: 883-895.

Keymeulen B, Vandemeulebroucke E, Ziegler AG, Mathieu C, Kaufman L, Hale G, Gorus F, Goldman M, Walter M, Candon S, et al. 2005. Insulin needs after CD3-antibody therapy in new-onset type 1 diabetes. $N$ Engl J Med 352: 2598-2608.

Khattri R, Cox T, Yasayko SA, Ramsdell F. 2003. An essential role for Scurfin in $\mathrm{CD} 4^{+} \mathrm{CD} 25^{+} \mathrm{T}$ regulatory cells. Nat Immunol 4: 337-342.

Kim JM, Rasmussen JP, Rudensky AY. 2007. Regulatory T cells prevent catastrophic autoimmunity throughout the lifespan of mice. Nat Immunol 8: 191-197.

Koch MA, Tucker-Heard G, Perdue NR, Killebrew JR, Urdahl KB, Campbell DJ. 2009. The transcription factor T-bet controls regulatory $\mathrm{T}$ cell homeostasis and function during type 1 inflammation. Nat Immunol 10: 595.

Kohlhaas S, Garden OA, Scudamore C, Turner M, Okkenhaug K, Vigorito E. 2009. Cutting edge: The Foxp3 target miR-155 contributes to the development of regulatory $\mathrm{T}$ cells. J Immunol. 182: 2578-2582.

Koralov SB, Muljo SA, Galler GR, Krek A, Chakraborty T, Kanellopoulou C, Jensen K, Cobb BS, Merkenschlager M, Rajewsky N, et al. 2008. Dicer ablation affects antibody diversity and cell survival in the B lymphocyte lineage. Cell 132: 860-874.

Korn T, Bettelli E, Oukka M, Kuchroo VK. 2009. IL-17 and Th17 Cells. Annu Rev Immunol 27: 485-517.

Lee JW, Epardaud M, Sun J, Becker JE, Cheng AC, Yonekura AR, Heath JK, Turley SJ. 2007. Peripheral antigen display by lymph node stroma promotes $\mathrm{T}$ cell tolerance to intestinal self. Nat Immunol 8: 181-190.

Lennon GP, Bettini M, Burton AR, Vincent E, Arnold PY, Santamaria P, Vignali DA. 2009. T cell islet accumulation in type 1 diabetes is a tightly regulated, cell-autonomous event. Immunity 31: 643-653.

Lenschow DJ, Herold KC, Rhee L, Patel B, Koons A, Qin HY, Fuchs E, Singh B, Thompson CB, Bluestone JA. 1996. CD28/B7 regulation of Th1 and Th2 subsets in the development of autoimmune diabetes. Immunity 5: 285-293.

Lieberman SM, DiLorenzo TP. 2003. A comprehensive guide to antibody and T-cell responses in type 1 diabetes. Tissue Antigens 62: 359-377.

Lim LP, Lau NC, Garrett-Engele P, Grimson A, Schelter JM, Castle J, Bartel DP, Linsley PS, Johnson JM. 2005. Microarray analysis shows that some microRNAs downregulate large numbers of target mRNAs. Nature 433: 769-773. 
Liston A, Lu LF, O'Carroll D, Tarakhovsky A, Rudensky AY 2008. Dicer-dependent microRNA pathway safeguards regulatory T cell function. J Exp Med 205: 1993-2004.

Liu W, Putnam AL, Xu-Yu Z, Szot GL, Lee MR, Zhu S, Gottlieb PA, Kapranov P, Gingeras TR, Fazekas de St Groth B, et al. 2006. CD127 expression inversely correlates with FoxP3 and suppressive function of human $\mathrm{CD}^{+}{ }^{+}$T reg cells. J Exp Med 203: 1701-1711.

Liu X, Alexiou M, Martin-Orozco N, Chung Y, Nurieva RI, Ma L, Tian Q, Kollias G, Lu S, Graf D, et al. 2009. Cutting edge: A critical role of $\mathrm{B}$ and $\mathrm{T}$ lymphocyte attenuator in peripheral $\mathrm{T}$ cell tolerance induction. J Immunol 182: 4516-4520.

Long SA, Cerosaletti K, Bollyky PL, Tatum M, Shilling H, Zhang S, Zhang ZY, Pihoker C, Sanda S, Greenbaum C, et al. 2010. Defects in IL-2R signaling contribute to diminished maintenance of FOXP3 expression in $\mathrm{CD} 4{ }^{+}$ $\mathrm{CD} 25^{+}$regulatory T-cells of type 1 diabetic subjects. Diabetes 59: 407-415.

Lu LF, Thai TH, Calado DP, Chaudhry A, Kubo M, Tanaka K, Loeb GB, Lee H, Yoshimura A, Rajewsky K, et al. 2009. Foxp3-dependent microRNA155 confers competitive fitness to regulatory $\mathrm{T}$ cells by targeting SOCS1 protein. Immunity 30: 80-91.

Lu LF, Boldin MP, Chaudhry A, Lin LL, Taganov KD, Hanada T, Yoshimura A, Baltimore D, Rudensky AY. 2010. Function of miR-146a in controlling Treg cell-mediated regulation of Th1 responses. Cell 142: 914-929.

Ludvigsson J. 2009. Therapy with GAD in diabetes. Diabetes Metab Res Rev 25: 307-315.

Ludvigsson J, Faresjo M, Hjorth M, Axelsson S, Cheramy M, Pihl M, Vaarala O, Forsander G, Ivarsson S, Johansson C, et al. 2008. GAD treatment and insulin secretion in recent-onset type 1 diabetes. $N$ Engl J Med 359: 19091920.

Ludvigsson J, Hjorth M, Cheramy M, Axelsson S, Pihl M, Forsander G, Nilsson NO, Samuelsson BO, Wood T, Aman J, et al. 2011. Extended evaluation of the safety and efficacy of GAD treatment of children and adolescents with recent-onset type 1 diabetes: A randomised controlled trial. Diabetologia 54: 634-640.

Luhder F, Hoglund P, Allison JP, Benoist C, Mathis D. 1998. Cytotoxic T lymphocyte-associated antigen 4 (CTLA-4) regulates the unfolding of autoimmune diabetes. J Exp Med 187: 427-432.

Luhder F, Chambers C, Allison JP, Benoist C, Mathis D. 2000. Pinpointing when $T$ cell costimulatory receptor CTLA-4 must be engaged to dampen diabetogenic T cells. Proc Natl Acad Sci 97: 12204-12209.

Luo X, Pothoven KL, McCarthy D, DeGutes M, Martin A, Getts DR, Xia G, He J, Zhang X, Kaufman DB, et al. 2008. ECDI-fixed allogeneic splenocytes induce donorspecific tolerance for long-term survival of islet transplants via two distinct mechanisms. Proc Natl Acad Sci 105: $14527-14532$.

Lyons PA, Armitage N, Argentina F, Denny P, Hill NJ, Lord CJ, Wilusz MB, Peterson LB, Wicker LS, Todd JA. 2000. Congenic mapping of the type 1 diabetes locus, Idd3, to a 780-kb region of mouse chromosome 3: Identification of a candidate segment of ancestral DNA by haplotype mapping. Genome Res 10: 446-453.
Breakdown in Peripheral Tolerance in T1D

Malek TR, Yu A, Vincek V, Scibelli P, Kong L. 2002. CD4 regulatory $\mathrm{T}$ cells prevent lethal autoimmunity in IL-2R $\beta$ deficient mice. Implications for the nonredundant function of IL-2. Immunity 17: 167-178.

Marson A, Kretschmer K, Frampton GM, Jacobsen ES, Polansky JK, MacIsaac KD, Levine SS, Fraenkel E, von Boehmer H, Young RA. 2007. Foxp3 occupancy and regulation of key target genes during T-cell stimulation. Nature 445: 931-935.

Martin-Orozco N, Chung Y, Chang SH, Wang YH, Dong C. 2009. Th17 cells promote pancreatic inflammation but only induce diabetes efficiently in lymphopenic hosts after conversion into Th1 cells. Eur J Immunol 39: 216224.

Matthews JB, Staeva TP, Bernstein PL, Peakman M, von Herrath M, ITN-JDRF Type,1 Diabetes Combination Therapy Assessment Group. 2010. Developing combination immunotherapies for type 1 diabetes: Recommendations from the ITN-JDRF Type 1 Diabetes Combination Therapy Assessment Group. Clin Exp Immunol 160: 176-184.

McClymont SA, Putnam AL, Lee MR, Esensten JH, Liu W, Hulme MA, Hoffmuller U, Baron U, Olek S, Bluestone JA, et al. 2011. Plasticity of human regulatory T cells in healthy subjects and patients with type 1 diabetes. J Immunol 186: 3918-3926.

McInerney MF, Pek SB, Thomas DW. 1991. Prevention of insulitis and diabetes onset by treatment with complete Freund's adjuvant in NOD mice. Diabetes 40: 715-725.

Meagher C, Tang Q, Fife BT, Bour-Jordan H, Wu J, Pardoux C, Bi M, Melli K, Bluestone JA. 2008. Spontaneous development of a pancreatic exocrine disease in CD28-deficient NOD mice. J Immunol 180: 7793-7803.

Miller SD, Turley DM, Podojil JR. 2007. Antigen-specific tolerance strategies for the prevention and treatment of autoimmune disease. Nat Rev Immunol 7: 665-677.

Monney L, Sabatos CA, Gaglia JL, Ryu A, Waldner H, Chernova T, Manning S, Greenfield EA, Coyle AJ, Sobel RA, et al. 2002. Th1-specific cell surface protein Tim-3 regulates macrophage activation and severity of an autoimmune disease. Nature 415: 536-541.

Mueller R, Krahl T, Sarvetnick N. 1996. Pancreatic expression of interleukin- 4 abrogates insulitis and autoimmune diabetes in nonobese diabetic (NOD) mice. J Exp Med 184: 1093-1099.

Nanto-Salonen K, Kupila A, Simell S, Siljander H, Salonsaari T, Hekkala A, Korhonen S, Erkkola R, Sipila JI, Haavisto L, et al. 2008. Nasal insulin to prevent type 1 diabetes in children with HLA genotypes and autoantibodies conferring increased risk of disease: A double-blind, randomised controlled trial. Lancet 372: 1746-1755.

Nielsen C, Hansen D, Husby S, Jacobsen BB, Lillevang ST. 2003. Association of a putative regulatory polymorphism in the PD-1 gene with susceptibility to type 1 diabetes. Tissue Antigens 62: 492-497.

O'Connell RM, Kahn D, Gibson WS, Round JL, Scholz RL, Chaudhuri AA, Kahn ME, Rao DS, Baltimore D. 2010. MicroRNA-155 promotes autoimmune inflammation by enhancing inflammatory $\mathrm{T}$ cell development. Immunity 33: 607-619.

Orban T, Bundy B, Becker DJ, DiMeglio LA, Gitelman SE, Goland R, Gottlieb PA, Greenbaum CJ, Marks JB, Monzavi R, et al. 2011. Type 1 Diabetes TrialNet Abatacept 


\section{L.T. Jeker et al}

Study Group. Co-stimulation modulation with abatacept in patients with recent-onset type 1 diabetes: A randomised, double-blind, placebo-controlled trial. Lancet 378: 412-419.

O'Shea JJ, Paul WE. 2010. Mechanisms underlying lineage commitment and plasticity of helper $\mathrm{CD}^{+}{ }^{+} \mathrm{T}$ cells. Science 327: 1098-1102.

Ogawa N, List JF, Habener JF, Maki T. 2004. Cure of overt diabetes in NOD mice by transient treatment with antilymphocyte serum and exendin-4. Diabetes 53: 17001705.

Ogawa N, Minamimura K, Kodaka T, Maki T. 2006. Short administration of polyclonal anti-T cell antibody (ALS) in NOD mice with extensive insulitis prevents subsequent development of autoimmune diabetes. J Autoimmun 26: 225-231.

Okada H, Kuhn C, Feillet H, Bach JF. 2010. The "hygiene hypothesis" for autoimmune and allergic diseases: An update. Clin Exp Immunol 160: 1-9.

Orban T, Farkas K, Jalahej H, Kis J, Treszl A, Falk B, Reijonen H, Wolfsdorf J, Ricker A, Matthews JB, et al. 2010. Autoantigen-specific regulatory $\mathrm{T}$ cells induced in patients with type 1 diabetes mellitus by insulin B-chain immunotherapy. J Autoimmun 34: 408-415.

Penaranda C, Tang Q, Bluestone JA. 2011. Anti-CD3 therapy promotes tolerance by selectively depleting pathogenic cells while preserving regulatory T cells. J Immunol 187: 2015-2022.

Ploix C, Bergerot I, Fabien N, Perche S, Moulin V, Thivolet C. 1998. Protection against autoimmune diabetes with oral insulin is associated with the presence of IL-4 type 2 T-cells in the pancreas and pancreatic lymph nodes. Diabetes 47: 39-44.

Posselt AM, Szot GL, Frassetto LA, Masharani U, Tavakol M Amin R, McElroy J, Ramos MD, Kerlan RK, Fong L, et al. 2010. Islet transplantation in type 1 diabetic patients using calcineurin inhibitor-free immunosuppressive protocols based on T-cell adhesion or costimulation blockade. Transplantation 90: 1595-1601.

Pozzilli P, Signore A, Williams AJ, Beales PE. 1993. NOD mouse colonies around the world-recent facts and figures. Immunol Today 14: 193-196.

Pugliese A, Zeller M, Fernandez A Jr, Zalcberg LJ, Bartlett RJ, Ricordi C, Pietropaolo M, Eisenbarth GS, Bennett ST, Patel DD. 1997. The insulin gene is transcribed in the human thymus and transcription levels correlated with allelic variation at the INS VNTR-IDDM2 susceptibility locus for type 1 diabetes. Nat Genet 15: 293-297.

Putnam AL, Brusko TM, Lee MR, Liu W, Szot GL, Ghosh T, Atkinson MA, Bluestone JA. 2009. Expansion of human regulatory T cells from patients with type 1 diabetes. Diabetes 58: 652-662.

Rahman AH, Cui W, Larosa DF, Taylor DK, Zhang J, Goldstein DR, Wherry EJ, Kaech SM, Turka LA. 2008. MyD88 plays a critical T cell-intrinsic role in supporting CD8 T cell expansion during acute lymphocytic choriomeningitis virus infection. J Immunol 181: 3804-3810.

Rapoport MJ, Jaramillo A, Zipris D, Lazarus AH, Serreze DV, Leiter EH, Cyopick P, Danska JS, Delovitch TL. 1993. Interleukin 4 reverses T cell proliferative unresponsiveness and prevents the onset of diabetes in nonobese diabetic mice. J Exp Med 178: 87-99.
Rodriguez A, Vigorito E, Clare S, Warren MV, Couttet $\mathrm{P}$, Soond DR, van Dongen S, Grocock RJ, Das PP, Miska EA, et al. 2007. Requirement of bic/microRNA-155 for normal immune function. Science 316: 608-611.

Roncarolo MG, Gregori S, Battaglia M, Bacchetta R, Fleischhauer K, Levings MK. 2006. Interleukin-10-secreting type 1 regulatory T cells in rodents and humans. Immunol Rev 212: $28-50$.

Rubtsov YP, Niec RE, Josefowicz S, Li L, Darce J, Mathis D, Benoist C, Rudensky AY. 2010. Stability of the regulatory T cell lineage in vivo. Science 329: 1667-1671.

Sadelain MW, Qin HY, Lauzon J, Singh B. 1990. Prevention of type I diabetes in NOD mice by adjuvant immunotherapy. Diabetes 39: 583-589.

Salomon B, Lenschow DJ, Rhee L, Ashourian N, Singh B, Sharpe A, Bluestone JA. 2000. B7/CD28 costimulation is essential for the homeostasis of the $\mathrm{CD} 4^{+} \mathrm{CD} 25^{+}$immunoregulatory $\mathrm{T}$ cells that control autoimmune diabetes. Immunity 12: 431-440.

Sanchez-Fueyo A, Tian J, Picarella D, Domenig C, Zheng XX, Sabatos CA, Manlongat N, Bender O, Kamradt T, Kuchroo VK, et al. 2003. Tim-3 inhibits T helper type 1mediated auto- and alloimmune responses and promotes immunological tolerance. Nat Immunol 4: 1093-1101.

Saudek F, Havrdova T, Boucek P, Karasova L, Novota P, Skibova J. 2004. Polyclonal anti-T-cell therapy for type 1 diabetes mellitus of recent onset. Rev Diabet Stud 1: 80-88.

Schneider A, Rieck M, Sanda S, Pihoker C, Greenbaum C, Buckner JH. 2008. The effector T cells of diabetic subjects are resistant to regulation via $\mathrm{CD} 4{ }^{+} \mathrm{FOXP} 3^{+}$regulatory T cells. J Immunol 181: 7350-7355.

Selbach M, Schwanhausser B, Thierfelder N, Fang Z, Khanin R, Rajewsky N. 2008. Widespread changes in protein synthesis induced by microRNAs. Nature 455: 58-63.

Serreze DV, Chapman HD, Post CM, Johnson EA, SuarezPinzon WL, Rabinovitch A. 2001. Th1 to Th2 cytokine shifts in nonobese diabetic mice: Sometimes an outcome, rather than the cause, of diabetes resistance elicited by immunostimulation. J Immunol 166: 1352-1359.

Setoguchi R, Hori S, Takahashi T, Sakaguchi S. 2005. Homeostatic maintenance of natural Foxp $3^{+}$CD $25^{+}$ $\mathrm{CD}^{+}{ }^{+}$regulatory $\mathrm{T}$ cells by interleukin (IL) -2 and induction of autoimmune disease by IL-2 neutralization. J Exp Med 201: 723-735.

Sherry NA, Chen W, Kushner JA, Glandt M, Tang Q, Tsai S, Santamaria P, Bluestone JA, Brillantes AM, Herold KC. 2007. Exendin-4 improves reversal of diabetes in NOD mice treated with anti-CD3 monoclonal antibody by enhancing recovery of $\beta$-cells. Endocrinology 148: 51365144.

Simon G, Parker M, Ramiya V, Wasserfall C, Huang Y, Bresson D, Schwartz RF, Campbell-Thompson M, Tenace L, Brusko T, et al. 2008. Murine antithymocyte globulin therapy alters disease progression in NOD mice by a time-dependent induction of immunoregulation. Diabetes 57: 405-414.

Smith JA, Tso JY, Clark MR, Cole MS, Bluestone JA. 1997. Nonmitogenic anti-CD3 monoclonal antibodies deliver a partial T cell receptor signal and induce clonal anergy. J Exp Med 185: 1413-1422.

Smith JA, Tang Q, Bluestone JA. 1998. Partial TCR signals delivered by FcR-nonbinding anti-CD3 monoclonal 
antibodies differentially regulate individual Th subsets. $J$ Immunol 160: 4841-4849.

Taganov KD, Boldin MP, Chang KJ, Baltimore D. 2006 NF- $\mathrm{KB}$-dependent induction of microRNA miR-146, an inhibitor targeted to signaling proteins of innate immune responses. Proc Natl Acad Sci 103: 12481-12486.

Tang Q, Bluestone JA. 2008. The Foxp $3^{+}$regulatory T cell: A jack of all trades, master of regulation. Nat Immunol 9: 239-244.

Tang Q, Henriksen KJ, Bi M, Finger EB, Szot G, Ye J, Masteller EL, McDevitt H, Bonyhadi M, Bluestone JA. 2004. In vitro-expanded antigen-specific regulatory $\mathrm{T}$ cells suppress autoimmune diabetes. J Exp Med 199: 1455-1465.

Tang Q, Adams JY, Tooley AJ, Bi M, Fife BT, Serra P, Santamaria P, Locksley RM, Krummel MF, Bluestone JA. 2006. Visualizing regulatory $\mathrm{T}$ cell control of autoimmune responses in nonobese diabetic mice. Nat Immunol 7: 83-92.

Tang Q, Adams JY, Penaranda C, Melli K, Piaggio E, Sgouroudis E, Piccirillo CA, Salomon BL, Bluestone JA. 2008 Central role of defective interleukin-2 production in the triggering of islet autoimmune destruction. Immunity 28: 687-697.

Thai TH, Calado DP, Casola S, Ansel KM, Xiao C, Xue Y Murphy A, Frendewey D, Valenzuela D, Kutok JL, et al. 2007. Regulation of the germinal center response by microRNA-155. Science 316: 604-608.

Thrower SL, James L, Hall W, Green KM, Arif S, Allen JS, Van-Krinks C, Lozanoska-Ochser B, Marquesini L, Brown S, et al. 2009. Proinsulin peptide immunotherapy in type 1 diabetes: Report of a first-in-man Phase I safety study. Clin Exp Immunol 155: 156-165.

Tian J, Atkinson MA, Clare-Salzler M, Herschenfeld A, Forsthuber T, Lehmann PV, Kaufman DL. 1996. Nasal administration of glutamate decarboxylase (GAD65) peptides induces Th2 responses and prevents murine insulin-dependent diabetes. J Exp Med 183: 1561-1567.

Todd JA, Walker NM, Cooper JD, Smyth DJ, Downes K, Plagnol V, Bailey R, Nejentsev S, Field SF, Payne F, et al. 2007. Robust associations of four new chromosome regions from genome-wide analyses of type 1 diabetes. Nat Genet 39: $857-864$.

Truong W, Hancock WW, Plester JC, Merani S, Rayner DC, Thangavelu G, Murphy KM, Anderson CC, Shapiro AM. 2009. BTLA targeting modulates lymphocyte phenotype, function, and numbers and attenuates disease in nonobese diabetic mice. J Leukoc Biol 86: 41-51.

Tsutsumi Y, Jie X, Ihara K, Nomura A, Kanemitsu S, Takada H, Hara T. 2006. Phenotypic and genetic analyses of Tcell-mediated immunoregulation in patients with Type 1 diabetes. Diabet Med 23: 1145-1150.

Turley S, Poirot L, Hattori M, Benoist C, Mathis D. 2003. Physiological $\beta$ cell death triggers priming of self-reactive T cells by dendritic cells in a type-1 diabetes model. J Exp Med 198: 1527-1537.

Turley SJ, Lee JW, Dutton-Swain N, Mathis D, Benoist C. 2005. Endocrine self and gut non-self intersect in the pancreatic lymph nodes. Proc Natl Acad Sci 102: 17729 17733.

Ueda H, Howson JM, Esposito L, Heward J, Snook H, Chamberlain G, Rainbow DB, Hunter KM, Smith AN, Di Genova G, et al. 2003. Association of the T-cell regu-
Breakdown in Peripheral Tolerance in T1D

latory gene CTLA4 with susceptibility to autoimmune disease. Nature 423: 506-511.

Vaarala O, Atkinson MA, Neu J. 2008. The "perfect storm" for type 1 diabetes: The complex interplay between intestinal microbiota, gut permeability, and mucosal immunity. Diabetes 57: 2555-2562.

van Belle TL, Coppieters KT, von Herrath MG. 2011. Type 1 diabetes: Etiology, immunology, and therapeutic strategies. Physiol Rev 91: 79-118.

Vang T, Congia M, Macis MD, Musumeci L, Orru V, Zavattari P, Nika K, Tautz L, Tasken K, Cucca F, et al. 2005. Autoimmune-associated lymphoid tyrosine phosphatase is a gain-of-function variant. Nat Genet 37: 1317-1319.

Vella A, Cooper JD, Lowe CE, Walker N, Nutland S, Widmer B, Jones R, Ring SM, McArdle W, Pembrey ME, et al. 2005. Localization of a type 1 diabetes locus in the IL2RA/CD25 region by use of tag single-nucleotide polymorphisms. Am J Hum Genet 76: 773-779.

Voltarelli JC, Couri CE, Stracieri AB, Oliveira MC, Moraes DA, Pieroni F, Coutinho M, Malmegrim KC, Foss-Freitas MC, Simoes BP, et al. 2007. Autologous nonmyeloablative hematopoietic stem cell transplantation in newly diagnosed type 1 diabetes mellitus. JAMA 297: 1568-1576.

von Herrath MG, Oldstone MB. 1997. Interferon- $\gamma$ is essential for destruction of $\beta$ cells and development of insulindependent diabetes mellitus. J Exp Med 185: 531-539.

Walker LS, Ausubel LJ, Chodos A, Bekarian N, Abbas AK. 2002. CTLA-4 differentially regulates $\mathrm{T}$ cell responses to endogenous tissue protein versus exogenous immunogen. J Immunol 169: 6202-6209.

Walter M, Philotheou A, Bonnici F, Ziegler AG, Jimenez R. 2009. No effect of the altered peptide ligand NBI-6024 on $\beta$-cell residual function and insulin needs in new-onset type 1 diabetes. Diabetes Care 32: 2036-2040.

Wang B, Gonzalez A, Hoglund P, Katz JD, Benoist C, Mathis D. 1998. Interleukin-4 deficiency does not exacerbate disease in NOD mice. Diabetes 47: 1207-1211.

Watanabe N, Gavrieli M, Sedy JR, Yang J, Fallarino F, Loftin SK, Hurchla MA, Zimmerman N, Sim J, Zang X, et al. 2003. BTLA is a lymphocyte inhibitory receptor with similarities to CTLA-4 and PD-1. Nat Immunol 4: 670679.

Weiner HL. 2001. The mucosal milieu creates tolerogenic dendritic cells and $\mathrm{T}(\mathrm{R}) 1$ and $\mathrm{T}(\mathrm{H}) 3$ regulatory cells. Nat Immunol 2: 671-672.

Weiner HL, da Cunha AP, Quintana F, Wu H. 2011. Oral tolerance. Immunol Rev 241: 241-259.

Wen L, Ley RE, Volchkov PY, Stranges PB, Avanesyan L, Stonebraker AC, Hu C, Wong FS, Szot GL, Bluestone JA, et al. 2008. Innate immunity and intestinal microbiota in the development of Type 1 diabetes. Nature 455: 1109-1113.

Wicker LS, Todd JA, Prins JB, Podolin PL, Renjilian RJ, Peterson LB. 1994. Resistance alleles at two non-major histocompatibility complex-linked insulin-dependent diabetes loci on chromosome 3, Idd3 and Idd10, protect nonobese diabetic mice from diabetes. J Exp Med 180: 17051713 .

Wing K, Onishi Y, Prieto-Martin P, Yamaguchi T, Miyara M, Fehervari Z, Nomura T, Sakaguchi S. 2008. CTLA-4 


\section{L.T. Jeker et al}

control over Foxp3 + regulatory T cell function. Science 322: $271-275$.

Wong FS, Wen L, Tang M, Ramanathan M, Visintin I, Daugherty J, Hannum LG, Janeway CA Jr, Shlomchik MJ. 2004. Investigation of the role of B-cells in type 1 diabetes in the NOD mouse. Diabetes 53: 2581-2587.

Xiao C, Rajewsky K. 2009. MicroRNA control in the immune system: Basic principles. Cell 136: 26-36.

Yamanouchi J, Rainbow D, Serra P, Howlett S, Hunter K, Garner VES., Gonzalez-Munoz A, Clark J, Veijola R, Cubbon $\mathrm{R}$, et al. 2007. Interleukin-2 gene variation impairs regulatory $\mathrm{T}$ cell function and causes autoimmunity. Nat Genet 39: 329-337.

Yip L, Su L, Sheng D, Chang P, Atkinson M, Czesak M, Albert PR, Collier AR, Turley SJ, Fathman CG, et al. 2009. Deaf1 isoforms control the expression of genes encoding peripheral tissue antigens in the pancreatic lymph nodes during type 1 diabetes. Nat Immunol 10: 1026-1033.

You S, Chen C, Lee WH, Brusko T, Atkinson M, Liu CP 2004. Presence of diabetes-inhibiting, glutamic acid decarboxylase-specific, IL-10-dependent, regulatory $\mathrm{T}$ cells in naive nonobese diabetic mice. J Immunol 173: 6777-6785.

You S, Belghith M, Cobbold S, Alyanakian MA, Gouarin C, Barriot S, Garcia C, Waldmann H, Bach JF, Chatenoud L. 2005. Autoimmune diabetes onset results from qualitative rather than quantitative age-dependent changes in pathogenic T-cells. Diabetes 54: 1415-1422.
You S, Leforban B, Garcia C, Bach JF, Bluestone JA, Chatenoud L. 2007. Adaptive TGF- $\beta$-dependent regulatory T cells control autoimmune diabetes and are a privileged target of anti-CD3 antibody treatment. Proc Natl Acad Sci 104: 6335-6340.

Zhang L, Nakayama M, Eisenbarth GS. 2008. Insulin as an autoantigen in NOD/human diabetes. Curr Opin Immunol 20: $111-118$.

Zheng Y, Josefowicz SZ, Kas A, Chu TT, Gavin MA, Rudensky AY. 2007. Genome-wide analysis of Foxp3 target genes in developing and mature regulatory T cells. Nature 445: 936-940.

Zheng Y, Chaudhry A, Kas A, deRoos P, Kim JM, Chu TT Corcoran L, Treuting P, Klein U, Rudensky AY. 2009. Regulatory T-cell suppressor program co-opts transcription factor IRF4 to control $\mathrm{T}(\mathrm{H}) 2$ responses. Nature 458: $351-356$.

Zhou X, Jeker LT, Fife BT, Zhu S, Anderson MS, McManus MT, Bluestone JA. 2008. Selective miRNA disruption in T reg cells leads to uncontrolled autoimmunity. J Exp Med 205: 1983-1991.

Zhou L, Chong MM, Littman DR. 2009a. Plasticity of CD4 ${ }^{+}$ $\mathrm{T}$ cell lineage differentiation. Immunity 30: 646-655.

Zhou X, Bailey-Bucktrout SL, Jeker LT, Penaranda C, Martinez-Llordella M, Ashby M, Nakayama M, Rosenthal W, Bluestone JA. 2009b. Instability of the transcription factor Foxp3 leads to the generation of pathogenic memory T cells in vivo. Nat Immunol 10: 1000-1007. 


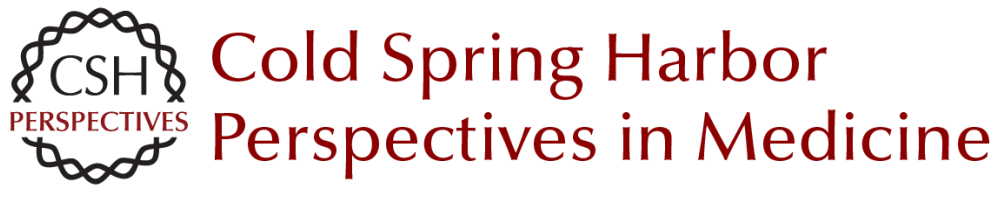

\title{
Breakdown in Peripheral Tolerance in Type 1 Diabetes in Mice and Humans
}

\author{
Lukas T. Jeker, Hélène Bour-Jordan and Jeffrey A. Bluestone
}

Cold Spring Harb Perspect Med 2012; doi: 10.1101/cshperspect.a007807 originally published online January 3, 2012

\section{Subject Collection Type I Diabetes}

The Pathogenesis and Natural History of Type 1

Diabetes

Mark A. Atkinson

Do MHCII-Presented Neoantigens Drive Type 1 Diabetes and Other Autoimmune Diseases? Philippa Marrack and John W. Kappler

Clinical Immunologic Interventions for the Treatment of Type 1 Diabetes Lucienne Chatenoud, Katharina Warncke and Anette-G. Ziegler

Update on Islet Transplantation Michael McCall and A.M. James Shapiro

Immunologic and Metabolic Biomarkers of $\beta$-Cell Destruction in the Diagnosis of Type 1 Diabetes Jasmin Lebastchi and Kevan C. Herold

Advancing Animal Models of Human Type 1 Diabetes by Engraftment of Functional Human

Tissues in Immunodeficient Mice Michael A. Brehm, Alvin C. Powers, Leonard D. Shultz, et al.

Breakdown in Peripheral Tolerance in Type 1 Diabetes in Mice and Humans Lukas T. Jeker, Hélène Bour-Jordan and Jeffrey $A$. Bluestone

Antigen-Specific Therapeutic Approaches in Type 1 Diabetes Xavier Clemente-Casares, Sue Tsai, Carol Huang, et al.
Humoral Autoimmunity in Type 1 Diabetes:

Prediction, Significance, and Detection of Distinct Disease Subtypes

Massimo Pietropaolo, Roberto Towns and George S. Eisenbarth

Endoplasmic Reticulum Stress, Pancreatic $\beta$-Cell Degeneration, and Diabetes Feroz R. Papa

Islet Autoantigens: Structure, Function, Localization, and Regulation Peter Arvan, Massimo Pietropaolo, David Ostrov, et al.

Environmental Triggers of Type 1 Diabetes Mikael Knip and Olli Simell

Generating $\beta$ Cells from Stem Cells--The Story So Far Matthias Hebrok

Antigen Targets of Type 1 Diabetes Autoimmunity Bart O. Roep and Mark Peakman

Connecting Type 1 and Type 2 Diabetes through Innate Immunity Justin I. Odegaard and Ajay Chawla

The Hygiene Hypothesis: An Explanation for the Increased Frequency of Insulin-Dependent Diabetes Jean-François Bach and Lucienne Chatenoud

For additional articles in this collection, see http://perspectivesinmedicine.cshlp.org/cgi/collection/ 